\title{
Hypoxia and Hypoxia-Inducible Factors in Kidney Injury and Repair
}

\author{
Shaoqun Shu ${ }^{1}$, Ying Wang ${ }^{1}$, Meiling Zheng ${ }^{1,2}$, Zhiwen Liu ${ }^{1}$, Juan Cai ${ }^{1}$, Chengyuan Tang ${ }^{1}$ and \\ Zheng Dong $1,3, * \mathbb{D}$ \\ 1 Department of Nephrology, The Second Xiangya Hospital of Central South University, Hunan Key \\ Laboratory of Kidney Disease and Blood Purification, Changsha 410011, China; 168211042@csu.edu.cn (S.S.); \\ 168211036@csu.edu.cn (Y.W.); zhengmeiling@sklmg.edu.cn (M.Z.); fry46152@163.com (Z.L.); \\ cjane218@csu.edu.cn (J.C.); tangchengyuan@csu.edu.cn (C.T.) \\ 2 The State Key Laboratory of Medical Genetics, School of Life Sciences, Central South University, \\ Changsha 410011, China \\ 3 Department of Cellular Biology and Anatomy, Medical College of Georgia at Augusta University and \\ Charlie Norwood VA Medical Center, Augusta, GA 30912, USA \\ * Correspondence: zdong@csu.edu.cn or zdong@augusta.edu
}

Received: 27 January 2019; Accepted: 25 February 2019; Published: 28 February 2019

check for updates

\begin{abstract}
Acute kidney injury (AKI) is a major kidney disease characterized by an abrupt loss of renal function. Accumulating evidence indicates that incomplete or maladaptive repair after AKI can result in kidney fibrosis and the development and progression of chronic kidney disease (CKD). Hypoxia, a condition of insufficient supply of oxygen to cells and tissues, occurs in both acute and chronic kidney diseases under a variety of clinical and experimental conditions. Hypoxia-inducible factors (HIFs) are the "master" transcription factors responsible for gene expression in hypoxia. Recent researches demonstrate that HIFs play an important role in kidney injury and repair by regulating HIF target genes, including microRNAs. However, there are controversies regarding the pathological roles of HIFs in kidney injury and repair. In this review, we describe the regulation, expression, and functions of HIFs, and their target genes and related functions. We also discuss the involvement of HIFs in AKI and kidney repair, presenting HIFs as effective therapeutic targets.
\end{abstract}

Keywords: hypoxia; HIF; kidney injury; kidney repair; prolyl hydroxylase domain-containing protein (PHD)

\section{Introduction}

Acute kidney injury (AKI), a major kidney disease with high morbidity and mortality, is characterized by a rapid loss of renal function [1]. The most common causes of AKI include sepsis, renal ischemia reperfusion (IR), and nephrotoxins. Pathologically, AKI is featured by sublethal and lethal injury of renal tubular epithelial cells [2,3]. Besides its acute effect on mortality, AKI can also contribute to the development and progression of chronic kidney disease (CKD) [4,5]. After initial injury, surviving renal proximal tubular epithelial cells (RPTCs) undergo dedifferentiation and proliferation to restore the integrity of renal tubules. However, when the injury becomes severe or episodic, the incomplete or maladaptive repair promotes the progression to CKD [6,7].

Hypoxia is a condition in which a cell or an organism has insufficient supply of oxygen. It occurs in microcirculation injury and hypoperfusion in tissues and organs including kidneys [8-10]. Hypoxia occurs in both AKI (not only the acute phase but also the recovery phase) and CKD under a variety of clinical and experimental conditions [11-15]. Meanwhile, it is also related to CKD-associated pathological states such as anemia [16] and inflammation [17]. The cellular response 
to hypoxia is centered on hypoxia-inducible factor (HIF). Under hypoxic condition, cells upregulate HIF, a well-known heterodimeric transcription factor that controls the transcription of more than 100 genes including erythropoietin (EPO), vascular endothelial growth factor (VEGF), and glucose transporter-1 (GLUT1) to restore tissue homeostasis by stimulating erythropoiesis, angiogenesis, anaerobic glycolysis, and other adaptive processes $[18,19]$. In kidneys, oxygen diffusion shunt between venous and arterial vessels that are in close physical relationship leads to a relatively low oxygen tension in kidney tissues, especially in renal medulla [20]. However, renal tubules are high in oxygen consumption [14]. Consequently, the low oxygen supply and high oxygen demand make the kidney vulnerable to hypoxia. Emerging evidence indicates that HIF and hypoxia response play an important role in various types of AKI [21-23] and CKD [14,15,24].

In this review, we will mainly concentrate on the function and mechanisms of HIF (HIF-1 and HIF-2) in kidney injury and repair, as they are the master transcriptional regulators responsive to hypoxia. We also discuss the therapeutic potential of targeting HIF for ameliorating kidney injury and accelerating kidney repair.

\section{Regulation of HIF}

HIF is a protein heterodimer that is composed of an inducible $\alpha$ subunit (HIF- $1 \alpha$, HIF- $2 \alpha$, or HIF- $3 \alpha$ ) and a constitutively expressed subunit HIF- $\beta$. Therefore, the expression and function of HIF mainly depends on HIF- $\alpha$. Notably, the stability of HIF- $\alpha$ is oxygen dependent. Under hypoxia, two critical prolyl residues of HIF- $\alpha$ are hydroxylated by specific prolyl hydroxylase domain-containing proteins (PHDs). Following prolyl hydroxylation, HIF- $\alpha$ binds to the von Hippel-Lindau protein (pVHL)-E3-ubiquitin ligase complex for ubiquitination and rapid degradation by proteasome $[25,26]$ (Figure 1). All PHDs (PHD1, PHD2, and PHD3) are expressed in renal tubular epithelial cells [27]. Higher levels of PHDs are found in the thick ascending limb, distal convoluted tubule, and collecting duct of inner medulla, where oxygen tension is known to be physiologically low. PHD1 is expressed in the nucleus, while PHD2 is expressed in the cytoplasm, and PHD3 is found both in the nucleus and cytoplasm [28]. Different PHDs have different roles. PHD2 is a key regulator of HIF- $\alpha$ expression [29], while the relative abundance of PHD3 and PHD1 may determine the selectivity of HIF- $1 \alpha$ and HIF- $2 \alpha$ expression [30]. What's more, PHD2 seems to be the hydroxylase that is essential for HIF- $\alpha$ degradation during normoxia $[29,31]$, whereas PHD3 appears to play an important role in hydroxylating HIF- $\alpha$ under reoxygenation [30].

In addition to PHDs, factor inhibiting HIF (FIH) is also a vital oxygen-sensitive enzyme for HIF regulation. With oxygen, FIH hydroxylates an HIF- $\alpha$ 's asparaginyl residue to prevent the recruitment of the CREB-binding protein (CBP)/p300 coactivators, which is required for the full transcriptional activity of HIF [32,33]. Thus, PHDs control the stability or expression level of HIF $\alpha$ s, while FIH1 regulates HIF's transcription activity, providing a dual mechanism of HIF upregulation in response to hypoxia (Figure 1). Of note, FIH1 remains active at lower oxygen concentrations than PHDs, and may therefore inhibit the activity of HIF that has escaped PHD-mediated destruction during moderate hypoxia $[34,35]$. Under hypoxia, HIF- $\alpha$ becomes stable and translocates into the nucleus, and then dimerizes with HIF- $\beta$ to transactivate target genes. Meanwhile, FIH inactivation promotes CBP/p300 recruitment for increasing the transcriptional activity of HIF [31]. In the kidneys, FIH has been detected in the distal tubules and podocytes [36].

Besides the classic regulation by PHDs and FIH, the stability, nuclear accumulation, and transcriptional activity of HIF- $\alpha$ are also modulated by other signaling pathways. Recent studies have indicated that direct phosphorylation of HIF- $\alpha$ plays an important role in regulating HIF- $\alpha$ stability, nuclear localization, as well as transcription activity [37]. Both glycogen synthase kinase-3beta (GSK- $3 \beta$ ) and polo-like kinase 3 (Plk3) can enhance HIF- $\alpha$ degradation by directly phosphorylating the HIF- $\alpha$ proteins $[38,39]$. In contrast, protein kinase A (PKA) may phosphorylate HIF-1 $\alpha$ to inhibit its proteasomal degradation and enhance its transcriptional activity [40]. Mylonis et al. demonstrated that phosphorylation of HIF- $1 \alpha$ by MAPK/ERK promoted its nuclear accumulation 
and transcriptional activity through blocking CRM1-dependent nuclear export [41,42]. Interestingly, ERK-dependent activation of HIF-1 could be inhibited by HIF-1 $\alpha$-derived cell-penetrating peptides [43].

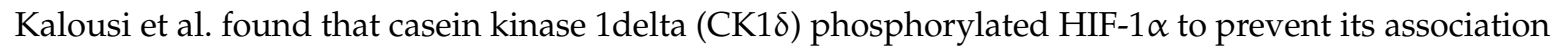
with HIF- $\beta$ and attenuate HIF-1 activity [44]. CK1 $\delta$ could also phosphorylate HIF- $2 \alpha$; however, this phosphorylation promoted the nuclear accumulation and transcription activity of HIF-2 $\alpha$ [45].

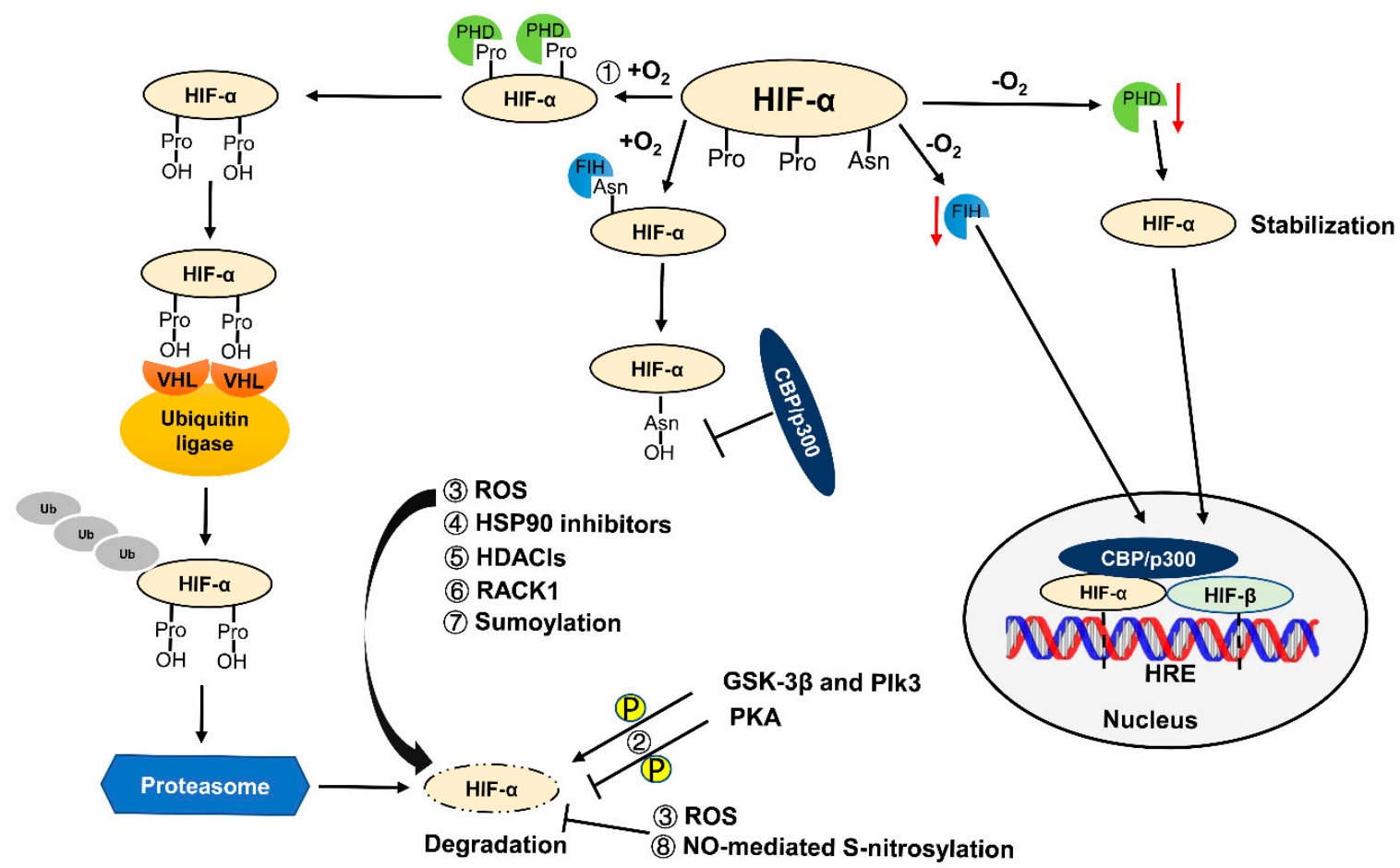

Figure 1. Regulation of the stability and transcription activity of HIF. In the presence of oxygen or normoxia, PHDs hydroxylate two prolyl residues of HIF- $\alpha$. The hydroxylated HIF- $\alpha$ then binds to VHL-E3-ubiquitin ligase complex, leading to poly-ubiquitination and proteosomal degradation. Meanwhile, FIH hydroxylates an asparaginyl residue of HIF- $\alpha$. Asparaginyl hydroxylated HIF- $\alpha$ prevents the recruitment of $\mathrm{CBP} / \mathrm{p} 300$ coactivators, which is required for the full transcriptional activity of HIF. In the absence of $\mathrm{O}_{2}$ or hypoxia, PHD-mediated prolyl residue hydroxylation is inhibited, resulting in HIF- $\alpha$ stabilization. The stabilized HIF- $\alpha$ translocates into nucleus and then dimerizes with HIF- $\beta$ to transactivate target genes. Meanwhile, FIH-mediated asparaginyl residue hydroxylation is also inhibited, causing the recruitment of CBP/p300 coactivators to enhance the transcription activity of HIF. In addition to oxygen, phosphorylation and ROS may play dual roles in HIF- $\alpha$ regulation; HSP90 inhibitors, HDACIs, RACK1, and sumoylation can decrease the stability of HIF- $\alpha$, while NO-mediated S-nitrosylation can enhance the stability of HIF- $\alpha$. Abbreviations: hypoxia-inducible factor (HIF), prolyl hydroxylase domain-containing protein (PHD), von Hippel-Lindau (VHL), factor inhibiting HIF (FIH), CREB-binding protein (CBP), hypoxia response element (HRE), reactive oxygen species (ROS), histone deacetylase inhibitors (HDACIs), receptor of activated protein kinase C 1 (RACK1), phosphorylation $(\mathrm{P})$, glycogen synthase kinase-3beta (GSK-3ß), polo-like kinase 3 (Plk3), protein kinase A (PKA), and nitric oxide (NO).

A growing number of studies, even if being conflicting, have indicated that reactive oxygen species (ROS) can regulate HIF- $\alpha$ under normoxia and hypoxia [46-48]. Under normoxia, ROS appear to act as signaling molecules for HIF-1 $\alpha$ [49]. Hypoxia results in increased production of ROS at the electron transport chain, which may increase HIF- $1 \alpha$ 's stability and activity by inhibiting PHD's activity $[50,51]$. Additional studies showed that increased ROS production could prevent hydroxylation and degradation of HIF- $1 \alpha$ and HIF-2 $\alpha$ [52]. However, other studies demonstrated that increased ROS promoted the degradation of HIF- $1 \alpha$ via the ubiquitin-proteasome system [48]. Thus, the regulation 
of HIF by ROS may depend on cellular and experimental context [47,52-54]. Moreover, it may involve the feedback through nuclear factor kappa B (NF-kB) and Nrf2 $[51,55,56]$.

In addition, heat shock protein 90 (HSP90) inhibitors and histone deacetylase inhibitors (HDACIs) were reported to accelerate HIF- $\alpha$ degradation in a manner independent of pVHL $[57,58]$. Receptor of activated protein kinase C 1 (RACK1) may prompt HIF-1 $\alpha$ degradation via competing with HSP90 [59]. Under certain conditions, nitric oxide (NO)-mediated S-nitrosylation can enhance the stability and activity of HIF-1 $\alpha$ [60]. In addition, sumoylation also plays a role in regulating HIF- $\alpha$ stability [61] (Figure 1).

\section{Expression Patterns and Functions of HIFs}

There are three subtypes of HIFs named HIF-1, HIF-2, and HIF-3 due to the labile subunit HIF- $\alpha$ (HIF- $1 \alpha$, HIF- $2 \alpha$, or HIF-3 $\alpha$ ). HIF- $1 \alpha$ is ubiquitously expressed in organs of most cell types, whereas HIF- $2 \alpha$ expression is tissue limited and detected particularly in highly vascularized tissues and organs [62,63]. In kidney, HIF- $1 \alpha$ is found in most renal epithelial cells, while HIF- $2 \alpha$ is mainly expressed in renal interstitial fibroblast-like cells and endothelial cells. In addition, HIF-1 $\alpha$ is also detected in endothelial and interstitial cells of the papilla and inner medulla, but not in the outer medulla and cortex [64].

In general, both HIF- $1 \alpha$ and HIF- $2 \alpha$ are activated by hypoxia but in different phases: HIF- $1 \alpha$ takes part in the initial adaptation process of hypoxia as it is rapidly induced and then falls to a low level within $72 \mathrm{~h}$, whereas HIF- $2 \alpha$ accumulation begins under prolonged hypoxic conditions [65-67]. Upon prolonged hypoxia, upregulated natural antisense RNA of HIF- $1 \alpha$ may destabilize HIF- $1 \alpha$ 's mRNA to decrease its expression in lung epithelial cells, whereas the expression of HIF-2 $\alpha$ is not affected [68]. Chen et al. showed that the elevated HIF-1 $\alpha$ under chronic hypoxic pulmonary hypertension may activate the transcription of PHD2 and PHD3, suggesting that upregulated PHDs under chronic hypoxia may act as a negative feedback mechanism for HIF-1 $\alpha$ [69]. Later research indicates that LIMD1, a HIF-1 target gene, mediates a negative feedback for HIF- $1 \alpha$ degradation under chronic hypoxic conditions by modulating PHD2-LIMD1-VHL complex formation [70].

Functionally, HIF-1 plays an important role in regulating metabolism. It not only mediates the transition from oxidative metabolism to glycolysis to generate ATP in an oxygen-independent manner, but also mediates the subunit conversion in cytochrome c oxidase under hypoxic conditions to improve the efficiency of electron transfer [71,72]. In addition, HIF-1 also takes part in the regulation of fibrosis, cell death, and inflammation [73], although the underlying mechanisms are less clear. HIF-2 is a major regulator of erythropoietin production [16] and vessel remodeling in diseases [74,75]. In contrast, the function of HIF-3 remains largely unknown and controversial. There are studies that suggest full-length HIF-3 may act as an oxygen-regulated transcriptional activator for a unique transcriptional program in response to hypoxia. On the other hand, some short HIF-3 variants may suppress HIF-1 and HIF-2 by acting as dominant-negative inhibitors that compete for HIF- $\beta$ [76]. In addition, HIF-1 can transcriptionally activate the expression of HIF-3 $\alpha$, adding another layer of complexity [77].

\section{Well-Known HIF Target Genes and Their Functions in Kidney}

Under hypoxia, HIFs accumulate and bind to the hypoxia response elements (HRE) in the enhancer or promoter region of their target genes, resulting in transcription $[20,26,78]$. Both HIF-1 and HIF-2 promote oxygen delivery and cellular adaptation to hypoxia via stimulating multiple cellular and tissue responses, including erythropoiesis, angiogenesis, anaerobic glucose metabolism, iron metabolism, and adenosine and NO metabolism [18,19]. Among them, erythropoiesis, angiogenesis, and anaerobic glucose metabolism, which are respectively regulated by EPO, VEGF, and glycolytic genes, are the most important hypoxia responses in kidney injury and repair. There is evidence that glycolytic genes are predominantly regulated by HIF-1 [79], whereas VEGF and EPO induction are preferentially regulated by HIF-2 [80-82]. Interestingly, in cells lacking HIF-1, there is no 
induction of hypoxia responsive genes, suggesting that HIF-1 is a prerequisite for inducing this family of genes in some cells [83].

\subsection{Erythropoietin (EPO)}

EPO, a hematopoietic growth factor secreted by the kidney and liver, promotes red blood cells generation (erythropoiesis) in the bone marrow, thus enhancing the blood's oxygen carrying capacity [72]. Upon hypoxia, HIF accumulates and binds to the HRE of EPO in the $3^{\prime}$ enhancer region [20,84]. The chief function of EPO is to promote erythropoiesis. In the regulation of erythropoiesis, kidney is the most important oxygen sensor, which responds to systemic hypoxia, and then increase the production of EPO rapidly by renal interstitial fibroblast-like cells $[85,86]$. Liver can also produce EPO to promote erythropoiesis in an oxygen-dependent mode, but it is not sufficient to compensate the loss of kidney EPO in end-stage renal disease, leading to anemia that requires systemic treatment with recombinant EPO [87]. In addition, EPO can also protect against kidney injury by reducing apoptosis and inflammation, and increasing tubular cell proliferation [88].

\subsection{Vascular Endothelial Growth Factor (VEGF)}

VEGF, induced by hypoxia or ischemia, plays an important role in angiogenesis by activating the receptor tyrosine kinases (VEGFR-1, VEGFR-2, and VEGFR-3) [89,90]. The function of renal glomerulus is dependent on the specialized vasculature maintained by VEGF [91]. Overexpression of podocyte-derived VEGF in glomeruli leads to a collapsing glomerulopathy [92], whereas suppression of podocyte VEGF expression destroys the filtration barrier, resulting in protein leakage and glomerular thrombotic microangiopathy (TMA) [93].

\section{HIF in AKI and Mechanisms of HIF Signaling in AKI}

Depending on the condition of perfusion, the oxygen supply to the kidneys, especially the cortex, can vary significantly. Notably, the renal proximal tubule cells have very limited capacity of ATP production via anaerobic glycolysis, resulting in rapid consumption of, and high dependence on, oxygen in maintaining oxidative metabolism. These make the kidney susceptible to hypoxic damage. In hypoxia (or ischemia in vivo), HIFs play an important role in the pathogenesis of AKI.

\subsection{HIF in IR-Induced AKI}

Renal ischemia-reperfusion injury (IRI) is one of the main causes of AKI associated with a variety of clinical conditions, such as kidney transplantation, renal vascular occlusion, and cardiac arrest resuscitation [94]. The involvement of HIFs in kidney IRI has been demonstrated in numerous studies. Both ischemic pre-conditioning (caused by short-term ischemia) and hypoxia pre-conditioning (caused by carbon monoxide, which reduces tissue oxygen availability through blocking the oxygen carrying capacity of hemoglobin) can induce HIF, leading to resistance against subsequent IR injury $[95,96]$. Activating HIF- $1 \alpha$ and HIF- $2 \alpha$ by pretreatment with pharmacological PHDs inhibitors significantly reduced ischemic kidney injury by reducing apoptosis, macrophage infiltration, and vascular cell adhesion molecule 1 (VCAM1) expression, and upregulating HIF target genes [21,96-101]. However, the effect of post-ischemic treatment with pharmacological PHDs inhibitors is controversial. Jamadarkhana et al. found that administrating PHD inhibitor TRC160334 at $2 \mathrm{~h}, 6 \mathrm{~h}$, and $10 \mathrm{~h}$ post the onset of kidney ischemia activated the expression of HIF-1 and attenuated kidney injury by inducing heat shock protein 70 (HSP70) [102]. Also, administrating granulocyte colony-stimulating factor (G-CSF) and stem cell factor (SCF) $6 \mathrm{~h}$ after IRI also activated the expression of HIF-1 and reduced the degree of kidney tissue injury by upregulating the expression of VEGF and EPO [103]. But, other studies demonstrated that administrating PHD inhibitors after renal ischemia had no effects in attenuating AKI and renal fibrosis [99,100]. There are several possible causes of the apparent discrepancy between these studies [99,100,102]: (1) the frequency of the administration of PHD inhibitors-the research by Jamadarkhana et al. [102] involved repetitive application of PHD inhibitor, while the research 
by Wang et al. [99] included only single application; (2) the method of the administration of PHD inhibitors-the PHD inhibitor was administered by oral gavage by Kapitsinou et al. [100], while the PHD inhibitor was injected by Jamadarkhana et al. [102]; (3) Jamadarkhana et al. [102] tested various doses, whereas Wang et al. and Kapitsinou et al. $[99,100]$ tested only a single dose; and (4) the time of the administration of PHD inhibitors. Thus, there may be a narrow therapeutic window of PHD inhibitors for treatment when given post ischemia.

Conde et al. showed that short interfering RNA (siRNA) against HIF-1 $\alpha$ exacerbated renal IR injury [11]. A later study further demonstrated that inhibiting HIF-1 $\alpha$ by siRNA during reperfusion had deleterious effects on kidney injury and renal fibrosis by downregulating miR-127-3p and inducing its target gene Bcl6 [104]. Meanwhile, Zhang et al. discovered that HIF-1 $\alpha$ siRNA counteracted the protective effect of isoflurane on renal ischemia-reperfusion injury [105]. Hill et al. found that heterozygous HIF- $1 \alpha$ and HIF- $2 \alpha$ knockdown (KO) mice had more pronounced renal IR injury than wild-type littermates [98]. Using HIF- $2 \alpha$ knockdown mice, Kojima et al. demonstrated that HIF-2 protected against renal ischemia by ameliorating oxidative stress [106]. Remarkably, Kapitsinou et al. analyzed the functions of HIF-1 and HIF-2 in endothelial cells during renal IR injury by testing conditional endothelial cell (EC)-specific HIF-1 $\alpha$ and HIF-2 $\alpha$ double or single knockout mouse models, demonstrating that endothelial HIF-2, but not endothelial HIF-1, protected from renal ischemia-reperfusion injury by reducing the expression of VCAM1 [21].

Mechanistically, apart from the aforementioned mechanisms such as oxidative stress, upregulating HIF target genes, and reducing VCAM1 expression, several studies have demonstrated that HIF-induced microRNAs play important roles in ischemic AKI. MicroRNAs are short non-coding RNAs that control post-transcriptional gene expression by translational inhibition and/or mRNA degradation through binding to target gene mRNA. For example, our recent study showed that microRNA-489 is induced via HIF-1 in ischemic AKI to protect renal proximal tubules by targeting relevant genes [107]. Our latest research further demonstrated that HIF-1 induces miR-668 to protect against ischemic AKI via repressing MTP18 to preserve mitochondrial dynamics [108]. Conde et al. showed that downregulating miR-127-3p by HIF-1 $\alpha$ interference may promote induction of collagen I and $\alpha$-SMA, and loss of E-cadherin [104]. Meanwhile, HIF-1 may also protect against IR-induced kidney injury via miR-21 target pathways [101,109], further indicating that HIF may protect kidneys via microRNAs. On the other hand, HIF can also induce the expression of injurious microRNAs. For example, $m i R-687$ is induced via HIF-1 in proximal tubule cells in ischemic AKI, and blocking miR-687 attenuated kidney injury by preserving PTEN expression and attenuating renal apoptosis and cell cycle activation [110]. Thus, in addition to the induction of protective microRNAs, HIF may also induce injurious microRNAs. Regardless, all these studies supported an important role of HIFs in the pathogenesis of ischemia AKI. Interestingly, a recent study by Mathia and colleagues showed that miR-22 was induced to repress HIF-1 $\alpha$ in a mouse model of rhabdomyolysis-associated AKI. Specific antagonism of miR-22 resulted in HIF-1 $\alpha$ upregulation, but it was unable to ameliorate AKI likely due to the expression of both protective and injurious genes [111].

\subsection{HIF in Cisplatin-Induced AKI}

Induction and activation of HIF have also been implicated in the pathogenesis of nephrotoxic AKI. One such example is AKI induced by cisplatin, a chemotherapeutic drug widely used to treat various malignancies. During cisplatin treatment of cancer, more than one-quarter of patients developed kidney problems, especially AKI [112]. In addition to causing renal tubule cell death, cisplatin also induced vascular dysfunction, resulting in hypoperfusion or hypoxia in kidneys [113]. In vitro, proximal tubular cells preconditioned with hypoxia reduced cisplatin-induced apoptosis in HIF- $1 \alpha$-dependent manner. In addition, in vivo, rats preconditioned with carbon monoxide prior to cisplatin administration ameliorated cisplatin-induced AKI [114]. Consistently, activating HIF-1 by pretreatment with pharmacological PHDs inhibitors such as cobalt and FG-4592 significantly attenuated cisplatin-induced AKI by inhibiting mitochondrial signaling pathways and upregulating 
HIF target genes [22,115]. In addition to drug intervention, implantation of stem cells had sparked great interest in the area of kidney repair following AKI. Wang and colleagues found that human adipose-derived stem cells (hASCs) transfected with HIF-1 $\alpha$ provided obvious protective effects against cisplatin-induced kidney injury on tubular structure and renal function by suppressing inflammation, reducing renal tubular apoptosis and upregulating heme oxygenase 1 (HO-1) gene expression [116]. What's more, delayed administration of lithium promoted recovery from cisplatin or IRI-induced AKI by stabilizing pro-proliferative molecules including HIF-1 $\alpha$ [117].

In conclusion, these findings indicated that intrinsic HIF activation, even at a modest level, may benefit kidneys during cisplatin chemotherapy.

\subsection{HIF in Sepsis-Associated AKI}

Sepsis is a systemic inflammatory response caused by infection and is the most common contributing factor in the development of AKI [118]. The systemic inflammatory response can be initiated by bacterial lipopolysaccharide (LPS) and/or other microbial component into the lymph and circulatory system. Early research indicated that pre-conditioning with chronic hypoxia protected against LPS-induced AKI by attenuating oxidative stress and inflammatory cytokine release via enhancing the ratio of intrarenal antioxidant/oxidative protein [119]. In septic patients, EPO and HIF- $1 \alpha$ play important roles in the pathogenesis of sepsis-AKI [120]. He and colleagues reported that pre-conditioning with LPS led to HIF- $2 \alpha$ accumulation via NF- $\mathrm{KB}$ in endothelial cells, which was responsible for the resistance of the pre-conditioned mice to subsequent ischemic AKI [121]. Importantly, Stoyanoff et al. indicated that phosphorylated NF- $\kappa B, p 65$, and HIF-1 $\alpha$ were simultaneously overexpressed in LPS-induced renal damage, and EPO administration attenuated septic-AKI through decreasing HIF-1 $\alpha$ and NF- $\kappa B$ expression [122]. Consistently, landiolol hydrochloride, acting as an ultra-short-acting beta-blocker, attenuated LPS-induced AKI by ameliorating HIF-1 upregulation and normalizing inflammatory cytokines such as TNF- $\alpha$ [123]. Together, these results suggested that the activation of HIF-1 may be harmful during septic or LPS-induced AKI.

\subsection{HIF in AKI Induced by Other Causes}

There are reports that HIF also takes part in AKI induced by rhabdomyolysis [23], gentamicin [124], and contrast medium in combination of nitric oxide synthase (NOS) inhibitor and cyclooxygenase inhibitor [125]. Selectively activating HIF in renal tubules by Pax8-rtTA-based inducible knockout of von Hippel-Lindau protein (VHL-KO) protected against rhabdomyolysis-induced renal damage through a metabolic sHIFt to anaerobic energy metabolism [23]. In gentamicin-induced AKI, activating HIF-1 by continuous infusion of cobalt ameliorated renal damage by reducing renal tubular apoptosis and macrophage infiltration [124]. Early studies indicated that contrast medium could reduce renal oxygen tension via increasing tubular oxygen consumption for solute reabsorption and decreasing renal perfusion by vasoconstriction and peritubular capillaries compression $[126,127]$. In a multi-insult-AKI rat model caused by contrast medium, NOS inhibitor, and COX inhibitor, furosemide treatment ameliorated kidney injury with an unexpected HIF-1 $\alpha$ increase [125]. Thus, HIF induction is a common observation in various AKI models. Following induction, HIF generally has a renoprotective role but it may contribute to AKI under specific conditions (Table 1). 
Table 1. Summary of in vivo studies on the effect of HIFs in kidney injury.

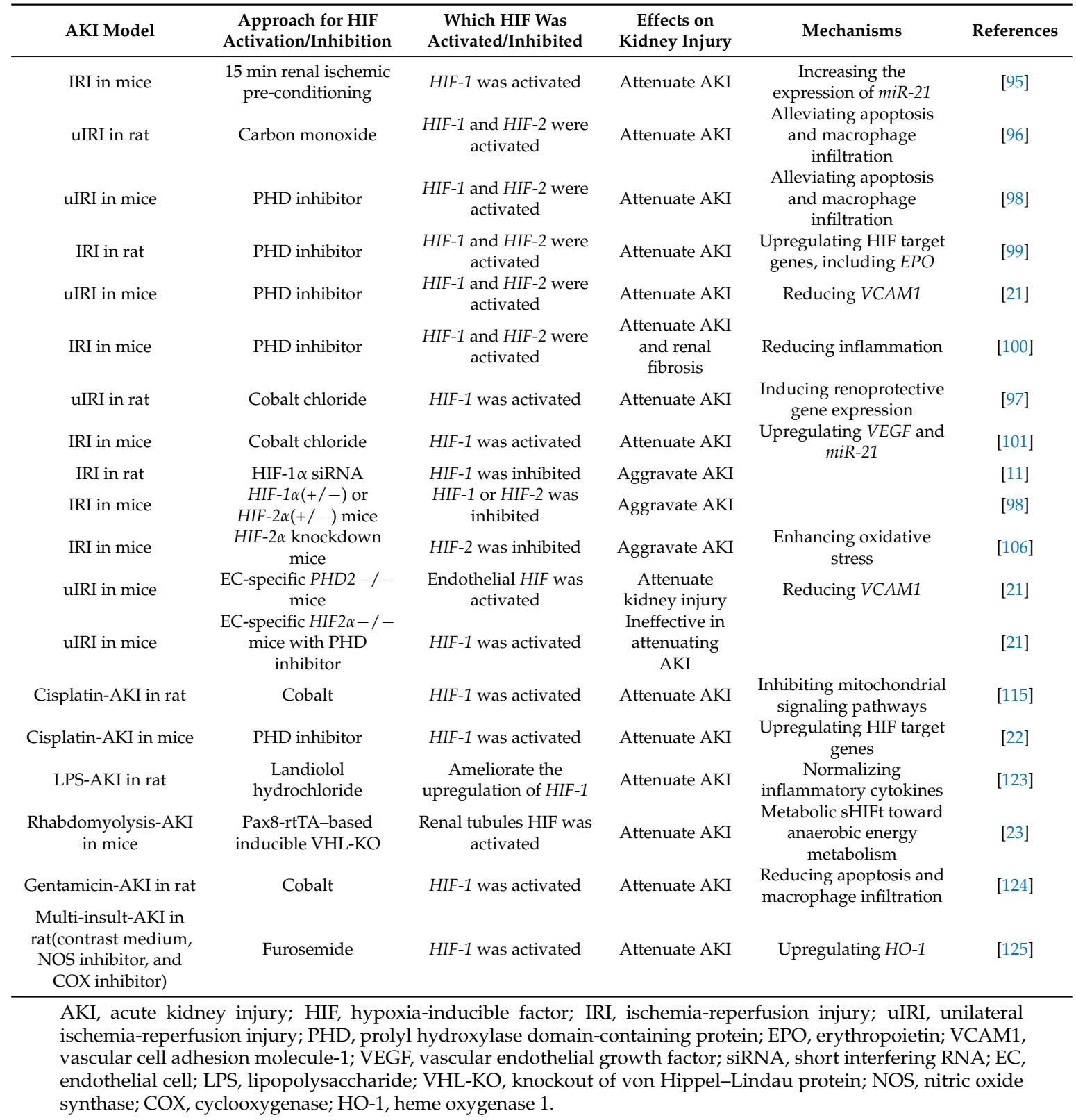

\section{Role of HIF in Kidney Repair}

After injury, the kidney has the capacity of repair. This is particularly true for renal tubules. If the initial injury is mild, kidney repair can be complete resulting in intact, fully functional repair; however, if the initial injury is severe, kidney repair is incomplete and may lead to chronic pathologies and gradual decline of renal function. HIFs have been implicated in kidney repair in various models (Table 2). 
Table 2. Summary of in vivo studies on the effect of HIFs in kidney repair.

\begin{tabular}{|c|c|c|c|c|c|}
\hline AKI Model & $\begin{array}{l}\text { Approach for HIF } \\
\text { Activation/Inhibition }\end{array}$ & $\begin{array}{c}\text { Which HIF was } \\
\text { Activated/Inhibited }\end{array}$ & $\begin{array}{l}\text { Effects on Kidney } \\
\text { Repair }\end{array}$ & Mechanisms & References \\
\hline IRI in rat & PHD inhibitor & HIF-1 was activated & Attenuate AKI & \multirow{3}{*}{$\begin{array}{c}\text { Inducing HSP70 } \\
\text { Upregulating VEGF } \\
\text { and } E P O \\
\text { Downregulating } \\
\text { miR-127-3p and } \\
\text { inducing its target } \\
\text { gene } B c l 6\end{array}$} & [102] \\
\hline IRI in rat & SCF and G-CSF & HIF-1 was activated & Attenuate AKI & & [103] \\
\hline IRI in rat & $H I F-1 \alpha$ siRNA & HIF-1 was inhibited & $\begin{array}{l}\text { Aggravate AKI and } \\
\text { renal fibrosis }\end{array}$ & & [104] \\
\hline IRI in rat & PHD inhibitor & $\begin{array}{l}\text { HIF-1 and HIF-2 were } \\
\text { activated }\end{array}$ & $\begin{array}{c}\text { Ineffective in } \\
\text { attenuating AKI }\end{array}$ & & [99] \\
\hline IRI in mice & PHD inhibitor & $\begin{array}{c}H I F-1 \text { and } H I F-2 \text { were } \\
\text { activated }\end{array}$ & $\begin{array}{l}\text { Ineffective in } \\
\text { attenuating } \mathrm{AKI} \text { and } \\
\text { renal fibrosis }\end{array}$ & & [100] \\
\hline IRI in rat & HIF- $1 \alpha$ siRNA & HIF-1 was inhibited & Aggravate AKI & & [11] \\
\hline uIRI in mice & $\begin{array}{l}\text { EC-specific HIF-1a } \\
H I F-2 \alpha-/- \text { mice }\end{array}$ & $\begin{array}{l}\text { Endothelial HIF-1 and } \\
\text { HIF-2 were inhibited }\end{array}$ & $\begin{array}{l}\text { Impair kidney } \\
\text { recovery and worsen } \\
\text { renal fibrosis }\end{array}$ & Activating $V C A M 1$ & [21] \\
\hline uIRI in mice & $\begin{array}{c}\text { EC-specific } \\
\text { HIF- } 1 \alpha-/- \text { or } \\
\text { HIF } 2 \alpha-/- \text { mice }\end{array}$ & $\begin{array}{l}\text { Endothelial HIF-1 or } \\
\text { HIF-2 was inhibited }\end{array}$ & $\begin{array}{c}\text { Inactivation of } \\
\text { endothelial HIF-2 but } \\
\text { not HIF-1 impairs } \\
\text { kidney recovery }\end{array}$ & Activating $V C A M 1$ & {$[21]$} \\
\hline $\begin{array}{l}\text { Cisplatin-AKI } \\
\text { in mice }\end{array}$ & $\begin{array}{c}\text { Lentivirus-mediated } \\
H I F-1 \alpha \text {-transfected } \\
\text { hASCs }\end{array}$ & HIF- 1 was activated & Attenuate AKI & Upregulating $\mathrm{HO}-1$ & [116] \\
\hline $\begin{array}{l}\text { LPS-AKI in } \\
\text { mice }\end{array}$ & $E P O$ & HIF-1 was inhibited & Attenuate AKI & $\begin{array}{l}\text { Promoting } \\
\text { angiogenesis }\end{array}$ & [122] \\
\hline
\end{tabular}

AKI, acute kidney injury; HIF, hypoxia-inducible factor; IRI, ischemia-reperfusion injury; PHD, prolyl hydroxylase domain-containing protein; HSP70, heat shock protein 70; SCF, stem cell factor; G-CSF, granulocyte colony-stimulating factor; VEGF, vascular endothelial growth factor; EPO, erythropoietin; siRNA, short interfering RNA; uIRI, unilateral ischemia-reperfusion injury; EC, endothelial cell; VCAM1, vascular cell adhesion molecule-1; hASCs, human adipose-derived stem cells; HO-1, heme oxygenase 1; LPS, lipopolysaccharide.

\subsection{Integral Introduction of Kidney Repair}

After AKI, the kidneys have the capability to repair damaged tubules. Depending on the severity of injury, the repair can be complete or incomplete. Complete repair (also called "adaptive repair") can restore the integrity and function of renal tubules, whereas incomplete or maladaptive repair, characterized by undifferentiated and atrophic tubules and persistent inflammation, leads to renal interstitial fibrosis and possible progression to CKD $[6,7,128,129]$. Tubulointerstitial hypoxia is considered to be a common pathway for progressive kidney disease. Hypoxia inhibits the growth of renal tubular epithelial cells and results in failure of remodeling by accelerating dedifferentiation and apoptosis $[130,131]$. In addition, hypoxia can also convert tubular epithelial cells to a pro-fibrotic phenotype [132] and promote tubulointerstitial inflammation [133]. Human microarray data have identified the hypoxia target genes in cell death (GsE12546), cellular proliferation (GsE4725), differentiation (GsE9510 and GsE4630) and inflammation (GsE968 and GsE10723) [134]. Although resident renal cells upregulate HIFs and relevant genes upon hypoxia, hypoxia adaptation through HIF is not sufficient in CKD as HIF is suppressed by many factors such as uremia and oxidative stress [135]. A list of in vivo studies on the effect of HIFs in kidney repair is presented in Table 2.

\subsection{HIF in Kidney Cell Death, Dedifferentiation, and Proliferation}

One mechanism for HIF involvement in kidney repair is by regulating kidney cell death. It is well known that appropriate kidney repair involves a precise balance between renal tubular cell death and proliferation [136]. Hypoxia may induce cell death of renal tubules and, to a limited extent, endothelial cells $[131,137]$. HIF- $1 \alpha$ affects cell death by regulating Bcl-2 family genes, interacting with p53, and/or targeting mitochondria enzymes [138]. A large amount of work has demonstrated that HIF activation decreases renal apoptosis in different kinds of AKI models [96,98,114-116]. Consistently, inhibiting HIF-1 in vitro by HIF- $1 \alpha$ interference promoted cell death [11]. In chronic models of progressive Thy1 nephritis and the remnant kidney, activating HIF by cobalt also reduced apoptotic tubular 
cells $[139,140]$. In addition, upregulated HIF- $1 \alpha$ promoted kidney tissue repair from acute tubular necrosis [103].

In non-lethal injury, proliferation and re-differentiation of proximal tubule cells are the major contributors to tubular repair [141]. Maladaptive tubular cells' repair may occur when epithelial cells are not fully re-differentiated [142] or arrested in G2 phase of cell cycle [143]. Many groups have indicated that surviving tubular cells could transiently upregulate tubular epithelial cell dedifferentiation markers such as alpha-smooth muscle actin, vimentin, and S100A4. Co-expression of PCNA-proliferating cell nuclear antigen with these markers indicated that the dedifferentiated cells are actively replicating $[144,145]$. In addition, The dedifferentiated cells respond to diverse proliferative signals, including epidermal growth factor (EGF), hepatocyte growth factor (HGF), transforming growth factor $\beta$ (TGF- $\beta$ ), and VEGF [146]. Under this condition, HIF- $1 \alpha$ may facilitate cell proliferation [147]. HIF-1 $\alpha$ induction during reperfusion acts as a key factor in proximal epithelial cell regeneration by promoting the expression of tissue repair genes [11]. In the remnant kidney model, HIF activation preserved the peritubular capillary networks by increasing the number of proliferating glomerular and peritubular endothelial cells [140]. Mechanistically, HIF-1 can enhance tissue repair by upregulating EPO to stimulate cellular regeneration as well as inhibit apoptotic cell death [148] and induce stromal cell-derived factor-1 (SDF-1) to promote recruitment of progenitor cells for regenerating tissues [149]. On the other hand, HIF-1 $\alpha$ can also inhibit cell proliferation [150]. A recent study reported that the induction of HIF-1 $\alpha$ during hypoxia inhibited the proliferation of mesenchymal stem cells through increasing the cell cycle inhibitor p27 [151]. What's more, HIF-1 $\alpha$ inhibition by siRNA induced proximal tubule cells proliferation during renal I/R [104]. Thus, in terms of tubular cell proliferation, HIF may be a double-sided sword.

\subsection{HIF in Kidney Fibrosis}

Maladaptive repair post-AKI leads to renal interstitial fibrosis [6]. Increasing evidence indicates that HIF is a pivotal regulator of kidney fibrosis under various pathological conditions [21,100,152]. However, it remains controversial whether HIF promotes or antagonizes renal fibrosis. In 2007, Higgins et al. demonstrated a critical role of renal tubular HIF-1 in renal fibrosis during unilateral ureteral obstruction (UUO) [24]. In ischemia-reperfusion injury, Kapitsinou et al. showed that activating HIF by pharmacological PHD inhibitor GSK1002083A before ischemia ameliorated AKI-induced fibrosis, but post-ischemic PHD inhibition had no effect on renal fibrosis [100]. In remnant kidney model, pharmacological activating HIF ameliorated tubulointerstitial injury and decreased fibrosis [140,153]. Further research indicated that the renoprotective effect of HIF in the remnant kidney model relied on the timing and isoform of HIF activation [154]. Administrating a PHD inhibitor (HIF stabilizer) at an early stage accelerated renal fibrosis, while administrating at a more advanced stage decreased renal fibrosis. Notably, the PHD inhibitor given at early stage activated both HIF- $1 \alpha$ and HIF- $2 \alpha$, whereas PHD inhibitor given later only activated HIF-2 $\alpha$ with no effect on HIF-1 $\alpha$ [154]. The time-dependent effects suggest that renal fibrosis in this model may be related to the activation of specific HIF isoforms in specific cells. In the model of hypertensive type 2 diabetes, pharmacological activating HIF by $\mathrm{CoCl}_{2}$ also attenuated renal fibrosis [155]. In contrast, Conde et al. found that HIF-1 $\alpha$ siRNA increased the expression of fibrotic markers and promoted the epithelial-to-mesenchymal transition (EMT) process in renal I/R [104]. Furthermore, Kobayashi and colleagues indicated that genetic activation of HIF suppressed fibrogenesis in UUO [156]. In addition, using genetic methods, Kapitsinou et al. demonstrated that inhibiting endothelial HIF accelerated renal fibrosis both in IR model and UUO model [21].

On the contrary, there are many studies demonstrated that HIF was pro-fibrotic in kidney. Kimura and his colleagues found that injection of a pharmacologic HIF-1 inhibitor (3-(5'-hydroxymethyl-2'-furyl)-1-benzyl indazole) decreased renal fibrosis in UUO [157]. In rat angiotensin II-induced renal injury and chronic ischemic renal injury, the increase of fibrotic proteins ( $\alpha$-smooth muscle actin and collagen) was blocked by HIF-1 $\alpha$ shRNA $[152,158]$. Consistently, 
in hypoxia / reoxygenation model, persistent activation of HIF- $1 \alpha$ by using an HIF- $1 \alpha \Delta$ ODD-expressing adenovirus significantly increased the expression of $\alpha$-smooth muscle actin and decreased the expression of E-cadherin [159]. Genetic ablation of proximal tubule epithelial HIF-1 $\alpha$ impeded the development of kidney fibrosis in UUO model [24]. Similarly, genetic overexpression of HIF-1 $\alpha$ in tubular epithelial cells by von Hippel-Lindau tumor suppressor $(V H L)$ deletion exacerbated interstitial fibrosis in a 5/6 renal ablation model [157]. Mechanistically, HIF signaling may promote renal fibrosis via at least four mechanisms: (1) transcriptional regulation of fibrogenic genes; (2) cross-talk with other pro-fibrotic signaling pathways such as TGF- $\beta$, NF-KB, Notch, and PI3K/Akt pathways; (3) its potential role in EMT; and (4) epigenetic regulation [73].

Collectively, these studies demonstrate an important regulatory role of HIF in renal fibrogenesis. However, whether HIF is pro- or anti-fibrotic may depend on which, where, and when HIF is activated.

\subsection{HIF in Kidney Inflammation}

Persistent inflammation is a characteristic of maladaptive kidney repair post AKI. Interestingly, inflammation and hypoxia often coexist and have been shown to regulate each other. On one hand, hypoxia and HIF-1 strongly influence inflammatory cell recruitment [160] and function [161]. On the other hand, inflammatory cells regulate the activation of hypoxic signaling pathways [162]. In the unilateral ischemia-reperfusion (uIR) and remnant kidney models, HIF activation by cobalt chloride decreased macrophage infiltration [97,140]. A latter study indicated that macrophages exhibited phenotype sHIFt (from M1 to M2) during the kidney repair process [163]. In a rat renal IR model, silencing HIF- $1 \alpha$ exacerbated inflammatory response by activating $N F-\kappa B$ and inducing pro-inflammatory factors [104]. In a mouse model of UUO, global or conditional knockout of HIF-1 and HIF-2 in myeloid cells caused more severe inflammation. In the meanwhile, activating HIF via myeloid-specific VHL-knockout suppresses inflammation [156]. Moreover, conditional knockout of endothelial HIF-2 $\alpha$, rather than HIF-1 $\alpha$, led to enhanced inflammatory cell infiltration in both uIR and UUO mouse models [21]. On the contrary, in renal epithelial cells, genetic ablation of HIF-1 $\alpha$ decreased inflammatory cell infiltration in mice UUO model [24]. Together, these studies indicate that HIF may play a modulatory role in inflammation in kidney injury and repair. HIF may suppress inflammation directly by working in immune cells and indirectly by working in epithelial and endothelial cells (Figure 2). 


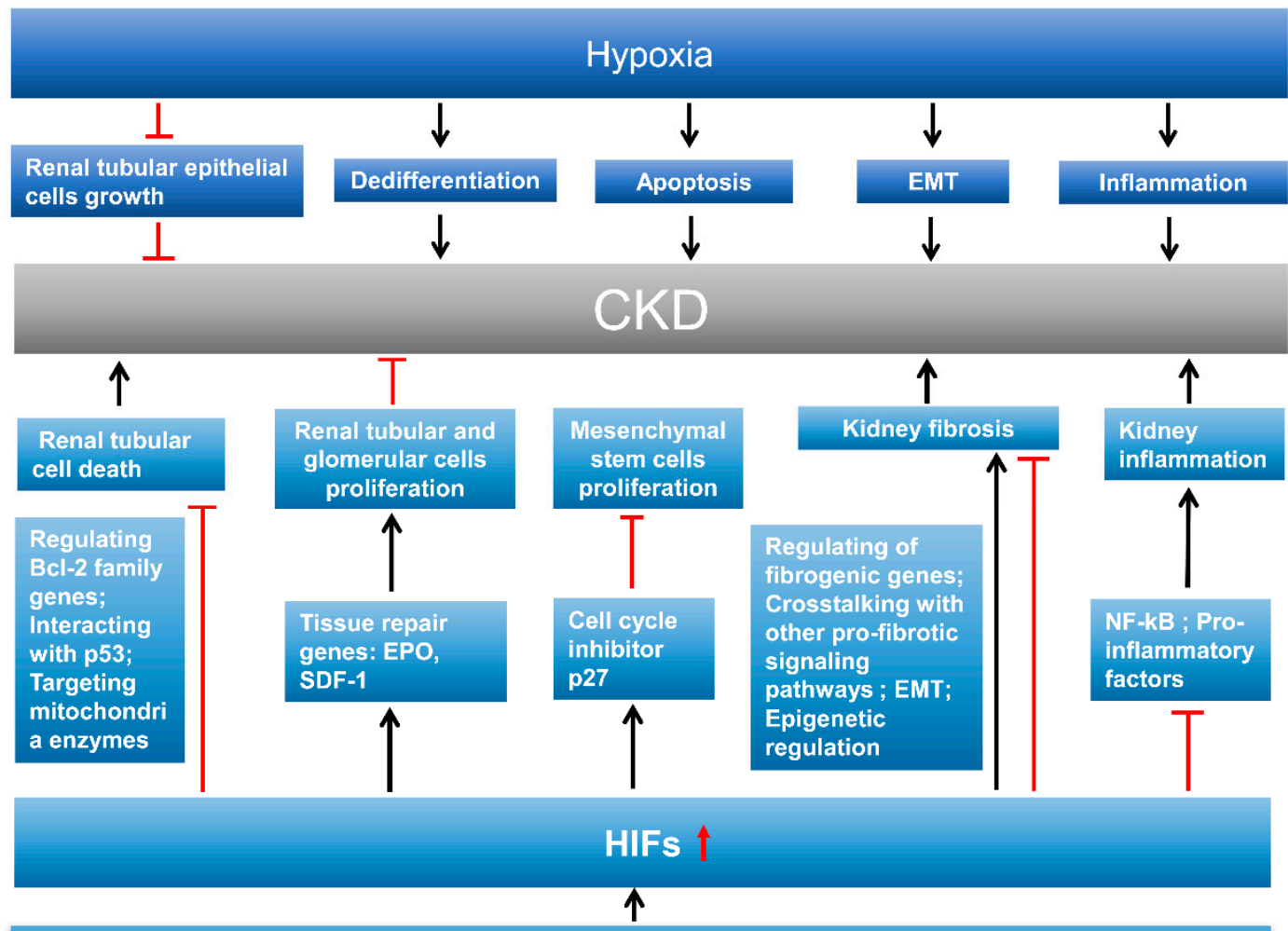

\section{Genetic or Pharmacological Treatment}

Figure 2. Role of hypoxia and HIF in kidney repair. Hypoxia accelerates the progression of CKD by inhibiting renal tubular epithelial cell growth and promoting dedifferentiation, apoptosis, EMT, and inflammation. Upregulation of HIFs by genetic or pharmacological treatment may (1) inhibit renal tubular cell death by regulating Bcl-2 family genes, interacting with p53, and/or targeting mitochondria enzymes; (2) promote renal tubular and glomerular cell proliferation by inducing tissue repair genes such as EPO and SDF-1; (3) inhibit mesenchymal stem cell proliferation by increasing the cell cycle inhibitor $p 27$ expression; (4) promote or inhibit kidney fibrosis by regulating fibrogenic genes, cross-talking with other pro-fibrotic signaling pathways, EMT, and epigenetic regulation; and (5) inhibit kidney inflammation by reducing the expression of $N F-\kappa B$ and pro-inflammatory factors. Abbreviations: epithelial-to-mesenchymal transition (EMT), chronic kidney disease (CKD), erythropoietin (EPO), stromal cell-derived factor-1 (SDF-1), and hypoxia-inducible factor (HIF).

\section{Therapeutic Potential of HIF in AKI and CKD}

HIF is the master switch for hypoxic adaptation in cells and tissues. In kidneys, as in other organs, HIF increases oxygen supply and improves the tolerance to conditions of hypoxia or ischemia in vivo. Hypoxia occurs frequently in diseased kidneys and HIF is often suboptimal under these conditions. This is particularly true for AKI and post-AKI kidneys under repair. Thus, there is a great therapeutic potential by targeting or activating HIF. As discussed above, HIF is primarily modulated by the PHD-VHL pathway. A major breakthrough in clinical application is that multiple clinical trials have shown the therapeutic effects of PHD inhibitors for anemia in CKD patients. The first PHD inhibitor, roxadustat, was recently approved for clinical use in China. Of note, these are Pan-PHD inhibitors and do not have specificity for a specific PHD isoform. There are three PHD isoforms that have different characteristics, including target selectivity for HIF- $\alpha$ isoforms and expression levels in cell types. Therefore, there is an urgent need to develop agents that can specifically inhibit each PHD isoform that are expected to be safer and have specific therapeutic spectrum. In addition, excessive activation of HIF may sometimes have deleterious effects. It is therefore important to systematically titrate and optimize the degree, timing, and duration of HIF activation. Finally, despite various experimental studies, it 
remains unclear if targeting HIF-PHD is an effective treatment for kidney diseases in human patients. In this regard, we expect serious efforts in both experimental and clinical test of PHD inhibitors in coming years.

Author Contributions: S.S. and Z.D. designed the outline; S.S. drafted the review; Z.D. and C.T. revised it; and all other authors provided suggestions.

Funding: The work was supported partly by the grants from National Key R\&D Program of China (2018YFC1312700).

Conflicts of Interest: The authors declare no conflict of interest.

\section{References}

1. Mehta, R.L.; Burdmann, E.A.; Cerda, J.; Feehally, J.; Finkelstein, F.; Garcia-Garcia, G.; Godin, M.; Jha, V.; Lameire, N.H.; Levin, N.W.; et al. Recognition and management of acute kidney injury in the International Society of Nephrology 0by25 Global Snapshot: A multinational cross-sectional study. Lancet 2016, 387, 2017-2025. [CrossRef]

2. Agarwal, A.; Dong, Z.; Harris, R.; Murray, P.; Parikh, S.M.; Rosner, M.H.; Kellum, J.A.; Ronco, C. Cellular and Molecular Mechanisms of AKI. J. Am. Soc. Nephrol. 2016, 27, 1288-1299. [CrossRef] [PubMed]

3. Linkermann, A.; Chen, G.; Dong, G.; Kunzendorf, U.; Krautwald, S.; Dong, Z. Regulated cell death in AKI. J. Am. Soc. Nephrol. 2014, 25, 2689-2701. [CrossRef] [PubMed]

4. He, L.; Wei, Q.; Liu, J.; Yi, M.; Liu, Y.; Liu, H.; Sun, L.; Peng, Y.; Liu, F.; Venkatachalam, M.A.; et al. AKI on CKD: Heightened injury, suppressed repair, and the underlying mechanisms. Kidney Int. 2017, 92, 1071-1083. [CrossRef] [PubMed]

5. Heung, M.; Steffick, D.E.; Zivin, K.; Gillespie, B.W.; Banerjee, T.; Hsu, C.Y.; Powe, N.R.; Pavkov, M.E.; Williams, D.E.; Saran, R.; et al. Acute Kidney Injury Recovery Pattern and Subsequent Risk of CKD: An Analysis of Veterans Health Administration Data. Am. J. Kidney Dis. 2016, 67, 742-752. [CrossRef] [PubMed]

6. Ferenbach, D.A.; Bonventre, J.V. Mechanisms of maladaptive repair after AKI leading to accelerated kidney ageing and CKD. Nat. Rev. Nephrol. 2015, 11, 264-276. [CrossRef] [PubMed]

7. Basile, D.P.; Bonventre, J.V.; Mehta, R.; Nangaku, M.; Unwin, R.; Rosner, M.H.; Kellum, J.A.; Ronco, C. Progression after AKI: Understanding Maladaptive Repair Processes to Predict and Identify Therapeutic Treatments. J. Am. Soc. Nephrol. 2016, 27, 687-697. [CrossRef] [PubMed]

8. Semenza, G.L. HIF-1, $\mathrm{O}_{2}$, and the 3 PHDs: How animal cells signal hypoxia to the nucleus. Cell 2001, 107, 1-3. [CrossRef]

9. Ohashi, R.; Shimizu, A.; Masuda, Y.; Kitamura, H.; Ishizaki, M.; Sugisaki, Y.; Yamanaka, N. Peritubular capillary regression during the progression of experimental obstructive nephropathy. J. Am. Soc. Nephrol. 2002, 13, 1795-1805. [CrossRef] [PubMed]

10. Matsumoto, M.; Tanaka, T.; Yamamoto, T.; Noiri, E.; Miyata, T.; Inagi, R.; Fujita, T.; Nangaku, M. Hypoperfusion of peritubular capillaries induces chronic hypoxia before progression of tubulointerstitial injury in a progressive model of rat glomerulonephritis. J. Am. Soc. Nephrol. 2004, 15, 1574-1581. [CrossRef] [PubMed]

11. Conde, E.; Alegre, L.; Blanco-Sanchez, I.; Saenz-Morales, D.; Aguado-Fraile, E.; Ponte, B.; Ramos, E.; Saiz, A.; Jimenez, C.; Ordonez, A.; et al. Hypoxia inducible factor $1-\alpha$ (HIF-1 $\alpha$ ) is induced during reperfusion after renal ischemia and is critical for proximal tubule cell survival. PLoS ONE 2012, 7, e33258. [CrossRef] [PubMed]

12. Rosenberger, C.; Pratschke, J.; Rudolph, B.; Heyman, S.N.; Schindler, R.; Babel, N.; Eckardt, K.U.; Frei, U.; Rosen, S.; Reinke, P. Immunohistochemical detection of hypoxia-inducible factor- $1 \alpha$ in human renal allograft biopsies. J. Am. Soc. Nephrol. 2007, 18, 343-351. [CrossRef] [PubMed]

13. Basile, D.P.; Donohoe, D.L.; Roethe, K.; Mattson, D.L. Chronic renal hypoxia after acute ischemic injury: Effects of L-arginine on hypoxia and secondary damage. Am. J. Physiol. Ren. Physiol. 2003, 284, F338-F348. [CrossRef] [PubMed]

14. Fu, Q.; Colgan, S.P.; Shelley, C.S. Hypoxia: The Force that Drives Chronic Kidney Disease. Clin. Med. Res. 2016, 14, 15-39. [CrossRef] [PubMed] 
15. Hirakawa, Y.; Tanaka, T.; Nangaku, M. Renal Hypoxia in CKD; Pathophysiology and Detecting Methods. Front. Physiol. 2017, 8, 99. [CrossRef] [PubMed]

16. Gruber, M.; Hu, C.J.; Johnson, R.S.; Brown, E.J.; Keith, B.; Simon, M.C. Acute postnatal ablation of HIF-2 $\alpha$ results in anemia. Proc. Natl. Acad. Sci. USA 2007, 104, 2301-2306. [CrossRef] [PubMed]

17. Rius, J.; Guma, M.; Schachtrup, C.; Akassoglou, K.; Zinkernagel, A.S.; Nizet, V.; Johnson, R.S.; Haddad, G.G.; Karin, M. NF- $\mathrm{B}$ links innate immunity to the hypoxic response through transcriptional regulation of HIF- $1 \alpha$. Nature 2008, 453, 807-811. [CrossRef] [PubMed]

18. Haase, V.H. Hypoxia-inducible factors in the kidney. Am. J. Physiol. Ren. Physiol. 2006, 291, F271-F281. [CrossRef] [PubMed]

19. Wenger, R.H.; Stiehl, D.P.; Camenisch, G. Integration of oxygen signaling at the consensus HRE. Sci. STKE 2005, 2005, re12. [CrossRef] [PubMed]

20. Nangaku, M.; Eckardt, K.U. Hypoxia and the HIF system in kidney disease. J. Mol. Med. 2007, 85, 1325-1330. [CrossRef] [PubMed]

21. Kapitsinou, P.P.; Sano, H.; Michael, M.; Kobayashi, H.; Davidoff, O.; Bian, A.; Yao, B.; Zhang, M.Z.; Harris, R.C.; Duffy, K.J.; et al. Endothelial HIF-2 mediates protection and recovery from ischemic kidney injury. J. Clin. Investig. 2014, 124, 2396-2409. [CrossRef] [PubMed]

22. Yang, Y.; Yu, X.; Zhang, Y.; Ding, G.; Zhu, C.; Huang, S.; Jia, Z.; Zhang, A. Hypoxia-inducible factor prolyl hydroxylase inhibitor roxadustat (FG-4592) protects against cisplatin-induced acute kidney injury. Clin. Sci. 2018, 132, 825-838. [CrossRef] [PubMed]

23. Fahling, M.; Mathia, S.; Paliege, A.; Koesters, R.; Mrowka, R.; Peters, H.; Persson, P.B.; Neumayer, H.H.; Bachmann, S.; Rosenberger, C. Tubular von Hippel-Lindau knockout protects against rhabdomyolysis-induced AKI. J. Am. Soc. Nephrol. 2013, 24, 1806-1819. [CrossRef] [PubMed]

24. Higgins, D.F.; Kimura, K.; Bernhardt, W.M.; Shrimanker, N.; Akai, Y.; Hohenstein, B.; Saito, Y.; Johnson, R.S.; Kretzler, M.; Cohen, C.D.; et al. Hypoxia promotes fibrogenesis in vivo via HIF-1 stimulation of epithelial-to-mesenchymal transition. J. Clin. Investig. 2007, 117, 3810-3820. [CrossRef] [PubMed]

25. Jaakkola, P.; Mole, D.R.; Tian, Y.M.; Wilson, M.I.; Gielbert, J.; Gaskell, S.J.; von Kriegsheim, A.; Hebestreit, H.F.; Mukherji, M.; Schofield, C.J.; et al. Targeting of HIF- $\alpha$ to the von Hippel-Lindau ubiquitylation complex by $\mathrm{O}_{2}$-regulated prolyl hydroxylation. Science 2001, 292, 468-472. [CrossRef] [PubMed]

26. Semenza, G.L. Oxygen sensing, homeostasis, and disease. N. Engl. J. Med. 2011, 365, 537-547. [CrossRef] [PubMed]

27. Soilleux, E.J.; Turley, H.; Tian, Y.M.; Pugh, C.W.; Gatter, K.C.; Harris, A.L. Use of novel monoclonal antibodies to determine the expression and distribution of the hypoxia regulatory factors PHD-1, PHD-2, PHD-3 and FIH in normal and neoplastic human tissues. Histopathology 2005, 47, 602-610. [CrossRef] [PubMed]

28. Schodel, J.; Klanke, B.; Weidemann, A.; Buchholz, B.; Bernhardt, W.; Bertog, M.; Amann, K.; Korbmacher, C.; Wiesener, M.; Warnecke, C.; et al. HIF-prolyl hydroxylases in the rat kidney: Physiologic expression patterns and regulation in acute kidney injury. Am. J. Pathol. 2009, 174, 1663-1674. [CrossRef] [PubMed]

29. Berra, E.; Benizri, E.; Ginouves, A.; Volmat, V.; Roux, D.; Pouyssegur, J. HIF prolyl-hydroxylase 2 is the key oxygen sensor setting low steady-state levels of HIF-1 $\alpha$ in normoxia. EMBO J. 2003, 22, 4082-4090. [CrossRef] [PubMed]

30. Appelhoff, R.J.; Tian, Y.M.; Raval, R.R.; Turley, H.; Harris, A.L.; Pugh, C.W.; Ratcliffe, P.J.; Gleadle, J.M. Differential function of the prolyl hydroxylases PHD1, PHD2, and PHD3 in the regulation of hypoxia-inducible factor. J. Biol. Chem. 2004, 279, 38458-38465. [CrossRef] [PubMed]

31. Kaelin, W.G., Jr.; Ratcliffe, P.J. Oxygen sensing by metazoans: The central role of the HIF hydroxylase pathway. Mol. Cell 2008, 30, 393-402. [CrossRef] [PubMed]

32. Mahon, P.C.; Hirota, K.; Semenza, G.L. FIH-1: A novel protein that interacts with HIF-1 $\alpha$ and VHL to mediate repression of HIF-1 transcriptional activity. Genes Dev. 2001, 15, 2675-2686. [CrossRef] [PubMed]

33. Lando, D.; Peet, D.J.; Whelan, D.A.; Gorman, J.J.; Whitelaw, M.L. Asparagine hydroxylation of the HIF transactivation domain a hypoxic switch. Science 2002, 295, 858-861. [CrossRef] [PubMed]

34. Dayan, F.; Roux, D.; Brahimi-Horn, M.C.; Pouyssegur, J.; Mazure, N.M. The oxygen sensor factor-inhibiting hypoxia-inducible factor-1 controls expression of distinct genes through the bifunctional transcriptional character of hypoxia-inducible factor- $1 \alpha$. Cancer Res. 2006, 66, 3688-3698. [CrossRef] [PubMed] 
35. Koivunen, P.; Hirsila, M.; Gunzler, V.; Kivirikko, K.I.; Myllyharju, J. Catalytic properties of the asparaginyl hydroxylase (FIH) in the oxygen sensing pathway are distinct from those of its prolyl 4-hydroxylases. J. Biol. Chem. 2004, 279, 9899-9904. [CrossRef] [PubMed]

36. Schodel, J.; Bohr, D.; Klanke, B.; Schley, G.; Schlotzer-Schrehardt, U.; Warnecke, C.; Kurtz, A.; Amann, K.; Eckardt, K.U.; Willam, C. Factor inhibiting HIF limits the expression of hypoxia-inducible genes in podocytes and distal tubular cells. Kidney Int. 2010, 78, 857-867. [CrossRef] [PubMed]

37. Kietzmann, T.; Mennerich, D.; Dimova, E.Y. Hypoxia-Inducible Factors (HIFs) and Phosphorylation: Impact on Stability, Localization, and Transactivity. Front. Cell Dev. Biol. 2016, 4, 11. [CrossRef] [PubMed]

38. Mennerich, D.; Dimova, E.Y.; Kietzmann, T. Direct phosphorylation events involved in HIF- $\alpha$ regulation: The role of GSK-3beta. Hypoxia 2014, 2, 35-45. [CrossRef] [PubMed]

39. Xu, D.; Dai, W.; Li, C. Polo-like kinase 3, hypoxic responses, and tumorigenesis. Cell Cycle 2017, 16, $2032-2036$. [CrossRef] [PubMed]

40. Bullen, J.W.; Tchernyshyov, I.; Holewinski, R.J.; DeVine, L.; Wu, F.; Venkatraman, V.; Kass, D.L.; Cole, R.N.; Van Eyk, J.; Semenza, G.L. Protein kinase A-dependent phosphorylation stimulates the transcriptional activity of hypoxia-inducible factor 1. Sci. Signal. 2016, 9, ra56. [CrossRef] [PubMed]

41. Mylonis, I.; Chachami, G.; Samiotaki, M.; Panayotou, G.; Paraskeva, E.; Kalousi, A.; Georgatsou, E.; Bonanou, S.; Simos, G. Identification of MAPK phosphorylation sites and their role in the localization and activity of hypoxia-inducible factor-1 $\alpha$. J. Biol. Chem. 2006, 281, 33095-33106. [CrossRef] [PubMed]

42. Mylonis, I.; Kourti, M.; Samiotaki, M.; Panayotou, G.; Simos, G. Mortalin-mediated and ERK-controlled targeting of HIF-1 $\alpha$ to mitochondria confers resistance to apoptosis under hypoxia. J. Cell Sci. 2017, 130, 466-479. [CrossRef] [PubMed]

43. Karagiota, A.; Kourti, M.; Simos, G.; Mylonis, I. HIF-1 $\alpha$-derived cell-penetrating peptides inhibit ERK-dependent activation of HIF-1 and trigger apoptosis of cancer cells under hypoxia. Cell. Mol. Life Sci. 2019, 76, 809-825. [CrossRef] [PubMed]

44. Kalousi, A.; Mylonis, I.; Politou, A.S.; Chachami, G.; Paraskeva, E.; Simos, G. Casein kinase 1 regulates human hypoxia-inducible factor HIF-1. J. Cell Sci. 2010, 123, 2976-2986. [CrossRef] [PubMed]

45. Pangou, E.; Befani, C.; Mylonis, I.; Samiotaki, M.; Panayotou, G.; Simos, G. HIF-2 $\alpha$ phosphorylation by CK1ס promotes erythropoietin secretion in liver cancer cells under hypoxia. J. Cell Sci. 2016, 129, 4213-4226. [CrossRef] [PubMed]

46. Taylor, C.T. Mitochondria and cellular oxygen sensing in the HIF pathway. Biochem. J. 2008, 409, 19-26. [CrossRef] [PubMed]

47. Kietzmann, T.; Gorlach, A. Reactive oxygen species in the control of hypoxia-inducible factor-mediated gene expression. Semin. Cell Dev. Biol. 2005, 16, 474-486. [CrossRef] [PubMed]

48. Zou, A.P.; Cowley, A.W., Jr. Reactive oxygen species and molecular regulation of renal oxygenation. Acta Physiol. Scand. 2003, 179, 233-241. [CrossRef] [PubMed]

49. Gorlach, A.; Kietzmann, T. Superoxide and derived reactive oxygen species in the regulation of hypoxia-inducible factors. Methods Enzymol. 2007, 435, 421-446. [CrossRef] [PubMed]

50. Semenza, G.L. Hypoxia-inducible factors: Coupling glucose metabolism and redox regulation with induction of the breast cancer stem cell phenotype. EMBO J. 2017, 36, 252-259. [CrossRef] [PubMed]

51. Lacher, S.E.; Levings, D.C.; Freeman, S.; Slattery, M. Identification of a functional antioxidant response element at the HIF1A locus. Redox Biol. 2018, 19, 401-411. [CrossRef] [PubMed]

52. Gorlach, A.; Dimova, E.Y.; Petry, A.; Martinez-Ruiz, A.; Hernansanz-Agustin, P.; Rolo, A.P.; Palmeira, C.M.; Kietzmann, T. Reactive oxygen species, nutrition, hypoxia and diseases: Problems solved? Redox Biol. 2015, 6, 372-385. [CrossRef] [PubMed]

53. Dehne, N.; Brune, B. Sensors, transmitters, and targets in mitochondrial oxygen shortage-a hypoxia-inducible factor relay story. Antioxid. Redox Signal 2014, 20, 339-352. [CrossRef] [PubMed]

54. Shvetsova, A.N.; Mennerich, D.; Keratar, J.M.; Hiltunen, J.K.; Kietzmann, T. Non-electron transfer chain mitochondrial defects differently regulate HIF-1 $\alpha$ degradation and transcription. Redox Biol. 2017, 12, 1052-1061. [CrossRef] [PubMed]

55. Bonello, S.; Zahringer, C.; BelAiba, R.S.; Djordjevic, T.; Hess, J.; Michiels, C.; Kietzmann, T.; Gorlach, A. Reactive oxygen species activate the HIF-1 $\alpha$ promoter via a functional NFkappaB site. Arterioscler. Thromb. Vas. Biol. 2007, 27, 755-761. [CrossRef] [PubMed] 
56. Al Taleb, Z.; Petry, A.; Chi, T.F.; Mennerich, D.; Gorlach, A.; Dimova, E.Y.; Kietzmann, T. Differential transcriptional regulation of hypoxia-inducible factor- $1 \alpha$ by arsenite under normoxia and hypoxia: Involvement of Nrf2. J. Mol. Med. 2016, 94, 1153-1166. [CrossRef] [PubMed]

57. Isaacs, J.S.; Jung, Y.J.; Mimnaugh, E.G.; Martinez, A.; Cuttitta, F.; Neckers, L.M. Hsp90 regulates a von Hippel Lindau-independent hypoxia-inducible factor-1 $\alpha$-degradative pathway. J. Biol. Chem. 2002, 277, 29936-29944. [CrossRef] [PubMed]

58. Kong, X.; Lin, Z.; Liang, D.; Fath, D.; Sang, N.; Caro, J. Histone deacetylase inhibitors induce VHL and ubiquitin-independent proteasomal degradation of hypoxia-inducible factor $1 \alpha$. Mol. Cell. Biol. 2006, 26, 2019-2028. [CrossRef] [PubMed]

59. Liu, Y.V.; Baek, J.H.; Zhang, H.; Diez, R.; Cole, R.N.; Semenza, G.L. RACK1 competes with HSP90 for binding to HIF- $1 \alpha$ and is required for $\mathrm{O}_{2}$-independent and HSP90 inhibitor-induced degradation of HIF-1 $\alpha$. Mol. Cell 2007, 25, 207-217. [CrossRef] [PubMed]

60. Li, F.; Sonveaux, P.; Rabbani, Z.N.; Liu, S.; Yan, B.; Huang, Q.; Vujaskovic, Z.; Dewhirst, M.W.; Li, C.Y. Regulation of HIF-1 $\alpha$ stability through S-nitrosylation. Mol. Cell 2007, 26, 63-74. [CrossRef] [PubMed]

61. Cheng, J.; Kang, X.; Zhang, S.; Yeh, E.T. SUMO-specific protease 1 is essential for stabilization of HIF1 $\alpha$ during hypoxia. Cell 2007, 131, 584-595. [CrossRef] [PubMed]

62. Minamishima, Y.A.; Kaelin, W.G., Jr. Reactivation of hepatic EPO synthesis in mice after PHD loss. Science 2010, 329, 407. [CrossRef] [PubMed]

63. Wiesener, M.S.; Jurgensen, J.S.; Rosenberger, C.; Scholze, C.K.; Horstrup, J.H.; Warnecke, C.; Mandriota, S.; Bechmann, I.; Frei, U.A.; Pugh, C.W.; et al. Widespread hypoxia-inducible expression of HIF-2 $\alpha$ in distinct cell populations of different organs. FASEB J. 2003, 17, 271-273. [CrossRef] [PubMed]

64. Rosenberger, C.; Mandriota, S.; Jurgensen, J.S.; Wiesener, M.S.; Horstrup, J.H.; Frei, U.; Ratcliffe, P.J.; Maxwell, P.H.; Bachmann, S.; Eckardt, K.U. Expression of hypoxia-inducible factor- $1 \alpha$ and $-2 \alpha$ in hypoxic and ischemic rat kidneys. J. Am. Soc. Nephrol. 2002, 13, 1721-1732. [CrossRef] [PubMed]

65. Koh, M.Y.; Powis, G. Passing the baton: The HIF switch. Trends Biochem. Sci. 2012, 37, 364-372. [CrossRef] [PubMed]

66. Bartoszewska, S.; Kochan, K.; Piotrowski, A.; Kamysz, W.; Ochocka, R.J.; Collawn, J.F.; Bartoszewski, R. The hypoxia-inducible miR-429 regulates hypoxia-inducible factor- $1 \alpha$ expression in human endothelial cells through a negative feedback loop. FASEB J. 2015, 29, 1467-1479. [CrossRef] [PubMed]

67. Holmquist-Mengelbier, L.; Fredlund, E.; Lofstedt, T.; Noguera, R.; Navarro, S.; Nilsson, H.; Pietras, A.; Vallon-Christersson, J.; Borg, A.; Gradin, K.; et al. Recruitment of HIF- $1 \alpha$ and HIF- $2 \alpha$ to common target genes is differentially regulated in neuroblastoma: HIF- $2 \alpha$ promotes an aggressive phenotype. Cancer Cell 2006, 10, 413-423. [CrossRef] [PubMed]

68. Uchida, T.; Rossignol, F.; Matthay, M.A.; Mounier, R.; Couette, S.; Clottes, E.; Clerici, C. Prolonged hypoxia differentially regulates hypoxia-inducible factor (HIF)- $1 \alpha$ and HIF- $2 \alpha$ expression in lung epithelial cells: Implication of natural antisense HIF-1 $\alpha$. J. Biol. Chem. 2004, 279, 14871-14878. [CrossRef] [PubMed]

69. Chen, Y.R.; Dai, A.G.; Hu, R.C. [Reciprocal regulation between hypoxia-inducible factor- $1 \alpha$ and its prolyl hydroxylases in hypoxic pulmonary hypertension rats]. Chin. J. Tuberc. Respir. Dis. 2006, 29, 668-673.

70. Foxler, D.E.; Bridge, K.S. A HIF-LIMD1 negative feedback mechanism mitigates the pro-tumorigenic effects of hypoxia. EMBO Mol. Med. 2018, 10, e8304. [CrossRef] [PubMed]

71. Fukuda, R.; Zhang, H.; Kim, J.W.; Shimoda, L.; Dang, C.V.; Semenza, G.L. HIF-1 regulates cytochrome oxidase subunits to optimize efficiency of respiration in hypoxic cells. Cell 2007, 129, 111-122. [CrossRef] [PubMed]

72. Thompson, C.B. Into Thin Air: How We Sense and Respond to Hypoxia. Cell 2016, 167, 9-11. [CrossRef] [PubMed]

73. Liu, J.; Wei, Q.; Guo, C.; Dong, G.; Liu, Y.; Tang, C.; Dong, Z. Hypoxia, HIF, and Associated Signaling Networks in Chronic Kidney Disease. Int. J. Mol. Sci. 2017, 18, 950. [CrossRef] [PubMed]

74. Skuli, N.; Liu, L.; Runge, A.; Wang, T.; Yuan, L.; Patel, S.; Iruela-Arispe, L.; Simon, M.C.; Keith, B. Endothelial deletion of hypoxia-inducible factor- $2 \alpha(\mathrm{HIF}-2 \alpha)$ alters vascular function and tumor angiogenesis. Blood 2009, 114, 469-477. [CrossRef] [PubMed]

75. Skuli, N.; Majmundar, A.J.; Krock, B.L.; Mesquita, R.C.; Mathew, L.K.; Quinn, Z.L.; Runge, A.; Liu, L.; Kim, M.N.; Liang, J.; et al. Endothelial HIF-2 $\alpha$ regulates murine pathological angiogenesis and revascularization processes. J. Clin. Investig. 2012, 122, 1427-1443. [CrossRef] [PubMed] 
76. Duan, C. Hypoxia-inducible factor 3 biology: Complexities and emerging themes. Am. J. Physiol. Cell Physiol. 2016, 310, C260-C269. [CrossRef] [PubMed]

77. Tanaka, T.; Wiesener, M.; Bernhardt, W.; Eckardt, K.U.; Warnecke, C. The human HIF (hypoxia-inducible factor)- $3 \alpha$ gene is a HIF-1 target gene and may modulate hypoxic gene induction. Biochem. J. 2009, 424, 143-151. [CrossRef] [PubMed]

78. Heyman, S.N.; Rosen, S.; Rosenberger, C. Hypoxia-inducible factors and the prevention of acute organ injury. Crit. Care 2011, 15, 209. [CrossRef] [PubMed]

79. Hu, C.J.; Wang, L.Y.; Chodosh, L.A.; Keith, B.; Simon, M.C. Differential roles of hypoxia-inducible factor $1 \alpha$ (HIF-1 $\alpha$ ) and HIF-2 $\alpha$ in hypoxic gene regulation. Mol. Cell. Biol. 2003, 23, 9361-9374. [CrossRef] [PubMed]

80. Morita, M.; Ohneda, O.; Yamashita, T.; Takahashi, S.; Suzuki, N.; Nakajima, O.; Kawauchi, S.; Ema, M.; Shibahara, S.; Udono, T.; et al. HLF/HIF-2 $\alpha$ is a key factor in retinopathy of prematurity in association with erythropoietin. EMBO J. 2003, 22, 1134-1146. [CrossRef] [PubMed]

81. Rankin, E.B.; Higgins, D.F.; Walisser, J.A.; Johnson, R.S.; Bradfield, C.A.; Haase, V.H. Inactivation of the arylhydrocarbon receptor nuclear translocator (Arnt) suppresses von Hippel-Lindau disease-associated vascular tumors in mice. Mol. Cell. Biol. 2005, 25, 3163-3172. [CrossRef] [PubMed]

82. Warnecke, C.; Zaborowska, Z.; Kurreck, J.; Erdmann, V.A.; Frei, U.; Wiesener, M.; Eckardt, K.U. Differentiating the functional role of hypoxia-inducible factor (HIF)- $1 \alpha$ and HIF- $\alpha$ (EPAS-1) by the use of RNA interference: Erythropoietin is a HIF-2 $\alpha$ target gene in Hep3B and Kelly cells. FASEB J. 2004, 18, 1462-1464. [CrossRef] [PubMed]

83. Wang, G.L.; Semenza, G.L. General involvement of hypoxia-inducible factor 1 in transcriptional response to hypoxia. Proc. Natl. Acad. Sci. USA 1993, 90, 4304-4308. [CrossRef] [PubMed]

84. Semenza, G.L.; Wang, G.L. A nuclear factor induced by hypoxia via de novo protein synthesis binds to the human erythropoietin gene enhancer at a site required for transcriptional activation. Mol. Cell. Biol. 1992, 12, 5447-5454. [CrossRef] [PubMed]

85. Fandrey, J. Oxygen-dependent and tissue-specific regulation of erythropoietin gene expression. Am. J. Physiol. Regul. Integr. Comp. Physiol. 2004, 286, R977-R988. [CrossRef] [PubMed]

86. Jelkmann, W. Molecular biology of erythropoietin. Int. Med. 2004, 43, 649-659. [CrossRef]

87. Scortegagna, M.; Ding, K.; Zhang, Q.; Oktay, Y.; Bennett, M.J.; Bennett, M.; Shelton, J.M.; Richardson, J.A.; Moe, O.; Garcia, J.A. HIF-2 $\alpha$ regulates murine hematopoietic development in an erythropoietin-dependent manner. Blood 2005, 105, 3133-3140. [CrossRef] [PubMed]

88. Vesey, D.A.; Cheung, C.; Pat, B.; Endre, Z.; Gobe, G.; Johnson, D.W. Erythropoietin protects against ischaemic acute renal injury. Nephrol. Dial. Transplant. 2004, 19, 348-355. [CrossRef] [PubMed]

89. Forsythe, J.A.; Jiang, B.H.; Iyer, N.V.; Agani, F.; Leung, S.W.; Koos, R.D.; Semenza, G.L. Activation of vascular endothelial growth factor gene transcription by hypoxia-inducible factor 1. Mol. Cell. Biol. 1996, 16, 4604-4613. [CrossRef] [PubMed]

90. Markovic-Mueller, S.; Stuttfeld, E.; Asthana, M.; Weinert, T.; Bliven, S.; Goldie, K.N.; Kisko, K.; Capitani, G.; Ballmer-Hofer, K. Structure of the Full-length VEGFR-1 Extracellular Domain in Complex with VEGF-A. Structure 2017, 25, 341-352. [CrossRef] [PubMed]

91. Keir, L.S.; Firth, R.; Aponik, L.; Feitelberg, D.; Sakimoto, S.; Aguilar, E.; Welsh, G.I.; Richards, A.; Usui, Y.; Satchell, S.C.; et al. VEGF regulates local inhibitory complement proteins in the eye and kidney. J. Clin. Investig. 2017, 127, 199-214. [CrossRef] [PubMed]

92. Eremina, V.; Sood, M.; Haigh, J.; Nagy, A.; Lajoie, G.; Ferrara, N.; Gerber, H.P.; Kikkawa, Y.; Miner, J.H.; Quaggin, S.E. Glomerular-specific alterations of VEGF-A expression lead to distinct congenital and acquired renal diseases. J. Clin. Investig. 2003, 111, 707-716. [CrossRef] [PubMed]

93. Eremina, V.; Jefferson, J.A.; Kowalewska, J.; Hochster, H.; Haas, M.; Weisstuch, J.; Richardson, C.; Kopp, J.B.; Kabir, M.G.; Backx, P.H.; et al. VEGF inhibition and renal thrombotic microangiopathy. N. Engl. J. Med. 2008, 358, 1129-1136. [CrossRef] [PubMed]

94. Bastin, A.J.; Ostermann, M.; Slack, A.J.; Diller, G.P.; Finney, S.J.; Evans, T.W. Acute kidney injury after cardiac surgery according to Risk/Injury/Failure/Loss/End-stage, Acute Kidney Injury Network, and Kidney Disease: Improving Global Outcomes classifications. J. Crit. Care 2013, 28, 389-396. [CrossRef] [PubMed]

95. Xu, X.; Kriegel, A.J.; Liu, Y.; Usa, K.; Mladinov, D.; Liu, H.; Fang, Y.; Ding, X.; Liang, M. Delayed ischemic preconditioning contributes to renal protection by upregulation of miR-21. Kidney Int. 2012, 82, 1167-1175. [CrossRef] [PubMed] 
96. Bernhardt, W.M.; Campean, V.; Kany, S.; Jurgensen, J.S.; Weidemann, A.; Warnecke, C.; Arend, M.; Klaus, S.; Gunzler, V.; Amann, K.; et al. Preconditional activation of hypoxia-inducible factors ameliorates ischemic acute renal failure. J. Am. Soc. Nephrol. 2006, 17, 1970-1978. [CrossRef] [PubMed]

97. Matsumoto, M.; Makino, Y.; Tanaka, T.; Tanaka, H.; Ishizaka, N.; Noiri, E.; Fujita, T.; Nangaku, M. Induction of renoprotective gene expression by cobalt ameliorates ischemic injury of the kidney in rats. J. Am. Soc. Nephrol. 2003, 14, 1825-1832. [CrossRef] [PubMed]

98. Hill, P.; Shukla, D.; Tran, M.G.; Aragones, J.; Cook, H.T.; Carmeliet, P.; Maxwell, P.H. Inhibition of hypoxia inducible factor hydroxylases protects against renal ischemia-reperfusion injury. J. Am. Soc. Nephrol. 2008, 19, 39-46. [CrossRef] [PubMed]

99. Wang, Z.; Schley, G.; Turkoglu, G.; Burzlaff, N.; Amann, K.U.; Willam, C.; Eckardt, K.U.; Bernhardt, W.M. The protective effect of prolyl-hydroxylase inhibition against renal ischaemia requires application prior to ischaemia but is superior to EPO treatment. Nephrol. Dial. Transplant. 2012, 27, 929-936. [CrossRef] [PubMed]

100. Kapitsinou, P.P.; Jaffe, J.; Michael, M.; Swan, C.E.; Duffy, K.J.; Erickson-Miller, C.L.; Haase, V.H. Preischemic targeting of HIF prolyl hydroxylation inhibits fibrosis associated with acute kidney injury. Am. J. Physiol. Ren. Physiol. 2012, 302, F1172-F1179. [CrossRef] [PubMed]

101. Xu, X.; Song, N.; Zhang, X.; Jiao, X.; Hu, J.; Liang, M.; Teng, J.; Ding, X. Renal Protection Mediated by Hypoxia Inducible Factor- $1 \alpha$ Depends on Proangiogenesis Function of miR-21 by Targeting Thrombospondin 1. Transplantation 2017, 101, 1811-1819. [CrossRef] [PubMed]

102. Jamadarkhana, P.; Chaudhary, A.; Chhipa, L.; Dubey, A.; Mohanan, A.; Gupta, R.; Deshpande, S. Treatment with a novel hypoxia-inducible factor hydroxylase inhibitor (TRC160334) ameliorates ischemic acute kidney injury. Am. J. Nephrol. 2012, 36, 208-218. [CrossRef] [PubMed]

103. Bi, L.Y.; Zhao, D.A.; Yang, D.S.; Guo, J.G.; Liang, B.; Zhang, R.X.; Zhao, J.L.; Bai, H.T.; Li, S.J. Effects of autologous SCF- and G-CSF-mobilized bone marrow stem cells on hypoxia-inducible factor-1 in rats with ischemia-reperfusion renal injury. Genet. Mol. Res. 2015, 14, 4102-4112. [CrossRef] [PubMed]

104. Conde, E.; Gimenez-Moyano, S.; Martin-Gomez, L.; Rodriguez, M.; Ramos, M.E.; Aguado-Fraile, E.; Blanco-Sanchez, I.; Saiz, A.; Garcia-Bermejo, M.L. HIF-1 $\alpha$ induction during reperfusion avoids maladaptive repair after renal ischemia/reperfusion involving miR127-3p. Sci. Rep. 2017, 7, 41099. [CrossRef] [PubMed]

105. Zhang, L.; Huang, H.; Cheng, J.; Liu, J.; Zhao, H.; Vizcaychipi, M.P.; Ma, D. Pre-treatment with isoflurane ameliorates renal ischemic-reperfusion injury in mice. Life Sci. 2011, 88, 1102-1107. [CrossRef] [PubMed]

106. Kojima, I.; Tanaka, T.; Inagi, R.; Kato, H.; Yamashita, T.; Sakiyama, A.; Ohneda, O.; Takeda, N.; Sata, M.; Miyata, T.; et al. Protective role of hypoxia-inducible factor- $2 \alpha$ against ischemic damage and oxidative stress in the kidney. J. Am. Soc. Nephrol. 2007, 18, 1218-1226. [CrossRef] [PubMed]

107. Wei, Q.; Liu, Y.; Liu, P.; Hao, J.; Liang, M.; Mi, Q.S.; Chen, J.K.; Dong, Z. MicroRNA-489 Induction by Hypoxia-Inducible Factor-1 Protects against Ischemic Kidney Injury. J. Am. Soc. Nephrol. 2016, 27, 2784-2796. [CrossRef] [PubMed]

108. Wei, Q.; Sun, H.; Song, S.; Liu, Y.; Liu, P.; Livingston, M.J.; Wang, J.; Liang, M.; Mi, Q.S.; Huo, Y.; et al. MicroRNA-668 represses MTP18 to preserve mitochondrial dynamics in ischemic acute kidney injury. J. Clin. Investig. 2018, 128, 5448-5464. [CrossRef] [PubMed]

109. Song, N.; Zhang, T.; Xu, X.; Lu, Z.; Yu, X.; Fang, Y.; Hu, J.; Jia, P.; Teng, J.; Ding, X. miR-21 Protects Against Ischemia/Reperfusion-Induced Acute Kidney Injury by Preventing Epithelial Cell Apoptosis and Inhibiting Dendritic Cell Maturation. Front. Physiol. 2018, 9, 790. [CrossRef] [PubMed]

110. Bhatt, K.; Wei, Q.; Pabla, N.; Dong, G.; Mi, Q.S.; Liang, M.; Mei, C.; Dong, Z. MicroRNA-687 Induced by Hypoxia-Inducible Factor-1 Targets Phosphatase and Tensin Homolog in Renal Ischemia-Reperfusion Injury. J. Am. Soc. Nephrol. 2015, 26, 1588-1596. [CrossRef] [PubMed]

111. Mathia, S.; Rudigier, L.J.; Kasim, M.; Kirschner, K.M. A dual role of miR-22 in rhabdomyolysis-induced acute kidney injury. Acta Physiol. 2018, 224, e13102. [CrossRef] [PubMed]

112. Pabla, N.; Dong, Z. Cisplatin nephrotoxicity: Mechanisms and renoprotective strategies. Kidney Int. 2008, 73, 994-1007. [CrossRef] [PubMed]

113. Winston, J.A.; Safirstein, R. Reduced renal blood flow in early cisplatin-induced acute renal failure in the rat. Am. J. Physiol. 1985, 249, F490-F496. [CrossRef] [PubMed]

114. Weidemann, A.; Bernhardt, W.M.; Klanke, B.; Daniel, C.; Buchholz, B.; Campean, V.; Amann, K.; Warnecke, C.; Wiesener, M.S.; Eckardt, K.U.; et al. HIF activation protects from acute kidney injury. J. Am. Soc. Nephrol. 2008, 19, 486-494. [CrossRef] [PubMed] 
115. Tanaka, T.; Kojima, I.; Ohse, T.; Inagi, R.; Miyata, T.; Ingelfinger, J.R.; Fujita, T.; Nangaku, M. Hypoxia-inducible factor modulates tubular cell survival in cisplatin nephrotoxicity. Am. J. Physiol. Ren. Physiol. 2005, 289, F1123-F1133. [CrossRef] [PubMed]

116. Wang, W.W.; Li, Z.Z.; Wang, W.; Jiang, Y.; Cheng, J.; Lu, S.; Zhang, J.Y. Enhanced renoprotective effect of HIF-1 $\alpha$ modified human adipose-derived stem cells on cisplatin-induced acute kidney injury in vivo. Sci. Rep. 2015, 5, 10851. [CrossRef] [PubMed]

117. Bao, H.; Ge, Y.; Wang, Z.; Zhuang, S.; Dworkin, L.; Peng, A.; Gong, R. Delayed administration of a single dose of lithium promotes recovery from AKI. J. Am. Soc. Nephrol. 2014, 25, 488-500. [CrossRef] [PubMed]

118. Doi, K. Role of kidney injury in sepsis. J. Intensive Care 2016, 4, 17. [CrossRef] [PubMed]

119. Yang, C.C.; Ma, M.C.; Chien, C.T.; Wu, M.S.; Sun, W.K.; Chen, C.F. Hypoxic preconditioning attenuates lipopolysaccharide-induced oxidative stress in rat kidneys. J. Physiol. 2007, 582, 407-419. [CrossRef] [PubMed]

120. Schaalan, M.F.; Mohamed, W.A. Determinants of hepcidin levels in sepsis-associated acute kidney injury: Impact on pAKT/PTEN pathways? J. Immunotoxicol. 2016, 13, 751-757. [CrossRef] [PubMed]

121. He, K.; Chen, X.; Han, C.; Xu, L.; Zhang, J.; Zhang, M.; Xia, Q. Lipopolysaccharide-induced cross-tolerance against renal ischemia-reperfusion injury is mediated by hypoxia-inducible factor- $\alpha \alpha$-regulated nitric oxide production. Kidney Int. 2014, 85, 276-288. [CrossRef] [PubMed]

122. Stoyanoff, T.R.; Rodriguez, J.P.; Todaro, J.S.; Colavita, J.P.M.; Torres, A.M.; Aguirre, M.V. Erythropoietin attenuates LPS-induced microvascular damage in a murine model of septic acute kidney injury. Biomed. Pharmacother. 2018, 107, 1046-1055. [CrossRef] [PubMed]

123. Ogura, Y.; Jesmin, S.; Yamaguchi, N.; Oki, M.; Shimojo, N.; Islam, M.M.; Khatun, T.; Kamiyama, J.; Sakuramoto, H.; Hagiya, K.; et al. Potential amelioration of upregulated renal HIF-1 $\alpha$-endothelin-1 system by landiolol hydrochloride in a rat model of endotoxemia. Life Sci. 2014, 118, 347-356. [CrossRef] [PubMed]

124. Ahn, J.M.; You, S.J.; Lee, Y.M.; Oh, S.W.; Ahn, S.Y.; Kim, S.; Chin, H.J.; Chae, D.W.; Na, K.Y. Hypoxia-inducible factor activation protects the kidney from gentamicin-induced acute injury. PLoS ONE 2012, 7, e48952. [CrossRef] [PubMed]

125. Rosenberger, C.; Heyman, S.N.; Rosen, S.; Shina, A.; Goldfarb, M.; Griethe, W.; Frei, U.; Reinke, P.; Bachmann, S.; Eckardt, K.U. Up-regulation of HIF in experimental acute renal failure: Evidence for a protective transcriptional response to hypoxia. Kidney Int. 2005, 67, 531-542. [CrossRef] [PubMed]

126. Heyman, S.N.; Reichman, J.; Brezis, M. Pathophysiology of radiocontrast nephropathy: A role for medullary hypoxia. Investig. Radiol. 1999, 34, 685-691. [CrossRef]

127. Heyman, S.N.; Rosenberger, C.; Rosen, S. Regional alterations in renal haemodynamics and oxygenation: A role in contrast medium-induced nephropathy. Nephrol. Dial. Transplant. 2005, 20 (Suppl. 1), i6-i11. [CrossRef]

128. Grgic, I.; Campanholle, G.; Bijol, V.; Wang, C.; Sabbisetti, V.S.; Ichimura, T.; Humphreys, B.D.; Bonventre, J.V. Targeted proximal tubule injury triggers interstitial fibrosis and glomerulosclerosis. Kidney Int. 2012, 82, 172-183. [CrossRef] [PubMed]

129. Shu, S.; Zhu, J.; Liu, Z.; Tang, C.; Cai, J.; Dong, Z. Endoplasmic reticulum stress is activated in post-ischemic kidneys to promote chronic kidney disease. EBioMedicine 2018, 37, 269-280. [CrossRef] [PubMed]

130. Khan, S.; Cleveland, R.P.; Koch, C.J.; Schelling, J.R. Hypoxia induces renal tubular epithelial cell apoptosis in chronic renal disease. Lab. Investig. 1999, 79, 1089-1099. [PubMed]

131. Tanaka, T.; Hanafusa, N.; Ingelfinger, J.R.; Ohse, T.; Fujita, T.; Nangaku, M. Hypoxia induces apoptosis in SV40-immortalized rat proximal tubular cells through the mitochondrial pathways, devoid of HIF1-mediated upregulation of Bax. Biochem. Biophys. Res. Commun. 2003, 309, 222-231. [CrossRef]

132. Manotham, K.; Tanaka, T.; Matsumoto, M.; Ohse, T.; Inagi, R.; Miyata, T.; Kurokawa, K.; Fujita, T.; Ingelfinger, J.R.; Nangaku, M. Transdifferentiation of cultured tubular cells induced by hypoxia. Kidney Int. 2004, 65, 871-880. [CrossRef] [PubMed]

133. Li, Z.L.; Lv, L.L.; Tang, T.T.; Wang, B.; Feng, Y.; Zhou, L.T.; Cao, J.Y.; Tang, R.N.; Wu, M.; Liu, H.; et al. HIF-1 $\alpha$ inducing exosomal microRNA-23a expression mediates the cross-talk between tubular epithelial cells and macrophages in tubulointerstitial inflammation. Kidney Int. 2018, 95, 388-404. [CrossRef] [PubMed]

134. Lendahl, U.; Lee, K.L.; Yang, H.; Poellinger, L. Generating specificity and diversity in the transcriptional response to hypoxia. Nat. Rev. Genet. 2009, 10, 821-832. [CrossRef] [PubMed] 
135. Tanaka, T. Expanding roles of the hypoxia-response network in chronic kidney disease. Clin. Exp. Nephrol. 2016, 20, 835-844. [CrossRef] [PubMed]

136. Zuk, A.; Bonventre, J.V. Acute Kidney Injury. Ann. Rev. Med. 2016, 67, 293-307. [CrossRef] [PubMed]

137. Tanaka, T.; Miyata, T.; Inagi, R.; Kurokawa, K.; Adler, S.; Fujita, T.; Nangaku, M. Hypoxia-induced apoptosis in cultured glomerular endothelial cells: Involvement of mitochondrial pathways. Kidney Int. 2003, 64, 2020-2032. [CrossRef] [PubMed]

138. Sendoel, A.; Hengartner, M.O. Apoptotic cell death under hypoxia. Physiology 2014, 29, 168-176. [CrossRef] [PubMed]

139. Tanaka, T.; Matsumoto, M.; Inagi, R.; Miyata, T.; Kojima, I.; Ohse, T.; Fujita, T.; Nangaku, M. Induction of protective genes by cobalt ameliorates tubulointerstitial injury in the progressive Thy1 nephritis. Kidney Int. 2005, 68, 2714-2725. [CrossRef] [PubMed]

140. Tanaka, T.; Kojima, I.; Ohse, T.; Ingelfinger, J.R.; Adler, S.; Fujita, T.; Nangaku, M. Cobalt promotes angiogenesis via hypoxia-inducible factor and protects tubulointerstitium in the remnant kidney model. Lab. Investig. 2005, 85, 1292-1307. [CrossRef] [PubMed]

141. Bonventre, J.V. Maladaptive proximal tubule repair: Cell cycle arrest. Nephron Clin. Pract. 2014, 127, 61-64. [CrossRef] [PubMed]

142. Geng, H.; Lan, R.; Wang, G.; Siddiqi, A.R.; Naski, M.C.; Brooks, A.I.; Barnes, J.L.; Saikumar, P.; Weinberg, J.M.; Venkatachalam, M.A. Inhibition of autoregulated TGFbeta signaling simultaneously enhances proliferation and differentiation of kidney epithelium and promotes repair following renal ischemia. Am. J. Pathol. 2009, 174, 1291-1308. [CrossRef] [PubMed]

143. Yang, L.; Besschetnova, T.Y.; Brooks, C.R.; Shah, J.V.; Bonventre, J.V. Epithelial cell cycle arrest in G2/M mediates kidney fibrosis after injury. Nat. Med. 2010, 16, 535-543. [CrossRef] [PubMed]

144. Witzgall, R.; Brown, D.; Schwarz, C.; Bonventre, J.V. Localization of proliferating cell nuclear antigen, vimentin, c-Fos, and clusterin in the postischemic kidney. Evidence for a heterogenous genetic response among nephron segments, and a large pool of mitotically active and dedifferentiated cells. J. Clin. Investig. 1994, 93, 2175-2188. [CrossRef] [PubMed]

145. Witzgall, R.; O’Leary, E.; Gessner, R.; Ouellette, A.J.; Bonventre, J.V. Kid-1, a putative renal transcription factor: Regulation during ontogeny and in response to ischemia and toxic injury. Mol. Cell. Biol. 1993, 13, 1933-1942. [CrossRef] [PubMed]

146. Ishibe, S.; Cantley, L.G. Epithelial-mesenchymal-epithelial cycling in kidney repair. Curr. Opin. Nephrol. Hypertens. 2008, 17, 379-385. [CrossRef] [PubMed]

147. Qing, G.; Skuli, N.; Mayes, P.A.; Pawel, B.; Martinez, D.; Maris, J.M.; Simon, M.C. Combinatorial regulation of neuroblastoma tumor progression by N-Myc and hypoxia inducible factor HIF-1 $\alpha$. Cancer Res. 2010, 70, 10351-10361. [CrossRef] [PubMed]

148. Moore, E.; Bellomo, R. Erythropoietin (EPO) in acute kidney injury. Ann. Intensive Care 2011, 1, 3. [CrossRef] [PubMed]

149. Ceradini, D.J.; Kulkarni, A.R.; Callaghan, M.J.; Tepper, O.M.; Bastidas, N.; Kleinman, M.E.; Capla, J.M.; Galiano, R.D.; Levine, J.P.; Gurtner, G.C. Progenitor cell trafficking is regulated by hypoxic gradients through HIF-1 induction of SDF-1. Nat. Med. 2004, 10, 858-864. [CrossRef] [PubMed]

150. Koshiji, M.; Huang, L.E. Dynamic balancing of the dual nature of HIF-1 $\alpha$ for cell survival. Cell Cycle 2004, 3, 853-854. [CrossRef] [PubMed]

151. Kumar, S.; Vaidya, M. Hypoxia inhibits mesenchymal stem cell proliferation through HIF1 $\alpha$-dependent regulation of P27. Mol. Cell. Biochem. 2016, 415, 29-38. [CrossRef] [PubMed]

152. Wang, Z.; Zhu, Q.; Li, P.L.; Dhaduk, R.; Zhang, F.; Gehr, T.W.; Li, N. Silencing of hypoxia-inducible factor-1 $\alpha$ gene attenuates chronic ischemic renal injury in two-kidney, one-clip rats. Am. J. Physiol. Ren. Physiol. 2014, 306, F1236-F1242. [CrossRef] [PubMed]

153. Song, Y.R.; You, S.J.; Lee, Y.M.; Chin, H.J.; Chae, D.W.; Oh, Y.K.; Joo, K.W.; Han, J.S.; Na, K.Y. Activation of hypoxia-inducible factor attenuates renal injury in rat remnant kidney. Nephrol. Dial. Transplant. 2010, 25, 77-85. [CrossRef] [PubMed]

154. Yu, X.; Fang, Y.; Liu, H.; Zhu, J.; Zou, J.; Xu, X.; Jiang, S.; Ding, X. The balance of beneficial and deleterious effects of hypoxia-inducible factor activation by prolyl hydroxylase inhibitor in rat remnant kidney depends on the timing of administration. Nephrol. Dial. Transplant. 2012, 27, 3110-3119. [CrossRef] [PubMed] 
155. Ohtomo, S.; Nangaku, M.; Izuhara, Y.; Takizawa, S.; Strihou, C.; Miyata, T. Cobalt ameliorates renal injury in an obese, hypertensive type 2 diabetes rat model. Nephrol. Dial. Transplant. 2008, 23, 1166-1172. [CrossRef] [PubMed]

156. Kobayashi, H.; Gilbert, V.; Liu, Q.; Kapitsinou, P.P.; Unger, T.L.; Rha, J.; Rivella, S.; Schlondorff, D.; Haase, V.H. Myeloid cell-derived hypoxia-inducible factor attenuates inflammation in unilateral ureteral obstruction-induced kidney injury. J. Immunol. 2012, 188, 5106-5115. [CrossRef] [PubMed]

157. Kimura, K.; Iwano, M.; Higgins, D.F.; Yamaguchi, Y.; Nakatani, K.; Harada, K.; Kubo, A.; Akai, Y.; Rankin, E.B.; Neilson, E.G.; et al. Stable expression of HIF-1 $\alpha$ in tubular epithelial cells promotes interstitial fibrosis. Am. J. Physiol. Ren. Physiol. 2008, 295, F1023-F1029. [CrossRef] [PubMed]

158. Zhu, Q.; Wang, Z.; Xia, M.; Li, P.L.; Van Tassell, B.W.; Abbate, A.; Dhaduk, R.; Li, N. Silencing of hypoxia-inducible factor- $1 \alpha$ gene attenuated angiotensin II-induced renal injury in Sprague-Dawley rats. Hypertension 2011, 58, 657-664. [CrossRef] [PubMed]

159. Luo, L.; Luo, G.; Fang, Q.; Sun, Z. Stable expression of hypoxia-inducible factor- $1 \alpha$ in human renal proximal tubular epithelial cells promotes epithelial to mesenchymal transition. Transplant. Proc. 2014, 46, 130-134. [CrossRef] [PubMed]

160. Kong, T.; Eltzschig, H.K.; Karhausen, J.; Colgan, S.P.; Shelley, C.S. Leukocyte adhesion during hypoxia is mediated by HIF-1-dependent induction of beta2 integrin gene expression. Proc. Natl. Acad. Sci. USA 2004, 101, 10440-10445. [CrossRef] [PubMed]

161. Cramer, T.; Yamanishi, Y.; Clausen, B.E.; Forster, I.; Pawlinski, R.; Mackman, N.; Haase, V.H.; Jaenisch, R.; Corr, M.; Nizet, V.; et al. HIF-1 $\alpha$ is essential for myeloid cell-mediated inflammation. Cell 2003, 112, 645-657. [CrossRef]

162. Yamaguchi, J.; Tanaka, T.; Eto, N.; Nangaku, M. Inflammation and hypoxia linked to renal injury by CCAAT/enhancer-binding protein $\delta$. Kidney Int. 2015, 88, 262-275. [CrossRef] [PubMed]

163. Anders, H.J.; Ryu, M. Renal microenvironments and macrophage phenotypes determine progression or resolution of renal inflammation and fibrosis. Kidney Int. 2011, 80, 915-925. [CrossRef] [PubMed]

(C) 2019 by the authors. Licensee MDPI, Basel, Switzerland. This article is an open access article distributed under the terms and conditions of the Creative Commons Attribution (CC BY) license (http:/ / creativecommons.org/licenses/by/4.0/). 